\title{
PENGARUH GAYA KEPEMIMPINAN, KETRAMPILAN KOMUNIKASI DAN KOTBAH TERHADAP KOMITMEN ORGANISASIONAL JEMAAT DI GKI DASA SURABAYA
}

\author{
Dr. F. Oscar L. Lontoh, M.Si.,Ak. \\ Sekolah Tinggi Teologi Injili Indonesia Surabaya \\ E-mail:oscarlontoh@sttii-surabaya.ac.id
}

Abstract. This research is titled The Influence of Leadership Style, Communication Competence and Sermon on Organizational Commitment at GKI Darmo Satelit Surabaya. The purpose of research is to identify and analyze whether Leadership Style, Communication Competence and Sermon have influence on the organizational commitment of congregation at GKI Darmo Satelit Surabaya. The population in this study were all congregation at GKI Darmo Satelit Surabaya. Samples of this study are 100 respondent. Through sampling stratified Random techniques.

These influence was measured using Pearson correlation coefficient and multiple regression analysis, $t$-test and analysis of variance. Descriptive analysis were taken to analyze organizational commitment levels according to demographic groups.

The hypothesis in this study are the Leadership Style, Communication Competence and Sermon have positive and significant on organizational commitment. The results showed that collectively, there are positive and significant correlation among Leadership Style, Communication Competence and Sermon on Organizational Commitment at GKI Darmo Satelit Surabaya 71,1\%. It means that 71,1\% of organizational commitment in GKI Darmo Satelit Surabaya influenced by Leadership style, communication competence and sermon and the other 28,9\% by others.

All of the variable partially have significant correlation to Organizational Commitment.

\section{Keywords: Organizational Commitment, Leadership Style, Communication Competence, Sermon.}

\section{PENDAHULUAN}

Fenomena bergereja di Indonesia akhir-akhir ini menjadi sesuatu yang menarik untuk diamati. Banyak terjadi anggota jemaat yang berpindah-pindah gereja seperti halnya orang pindah pekerjaan. Muncul suatu trend beribadah yang semakin memprihatinkan dikalangan umat Kristen di kota-kota besar, dimana banyak orang Kristen pergi beribadah namun dengan berpindah-pindah tempat. ${ }^{1}$ Yang terjadi saat ini banyak jemaat yang sering melakukan pindah gereja atau tidak mau menetap dalam suatu gereja lokal. Mereka cenderung untuk bergereja sesuai keinginan sesaat mereka. Banyaknya jemaat tidak memahami mengapa perlu terlibat dalam suatu gereja lokal. Sehingga mereka tidak memiliki komitmen dalam bersekutu di gereja lokal. Banyak orang Kristen yang merasa dirinya bebas memilih kemana mereka ingin pergi beribadah setiap hari minggu, pergi ke gereja namun tanpa memiliki komitmen dan keterlibatan khusus dengan gereja dimana mereka beribadah. Makna bergereja sekarang ini bergerak

menyimpang dari kegiatan ibadah komunal yang bersifat mutual kepada pilihan-pilihan dan selera individualis. Menurut Mimery gereja atau ekklesia adalah orang-orang (dalam arti jamak) yang telah dipanggil dari hidup dalam dosa untuk menjadi milik Tuhan Ekklesia ini menunjukkan kepada gereja yang tidak kelihatan maupun yang kelihatan. Gereja yang tidak kelihatan ini

www.reformata.com/new/view/6651/umat-kristentanpa-komitmen. termasuk didalamnya semua orang yang sudah bertobat dan menerima Injil sehingga Roh Suci melahirkan mereka kembali, dan membaptis mereka atau memasukkan mereka ke dalam sebuah Tubuh.Mereka berkumpul atau dikumpulkan dalam gereja atau jemaat, yang diorganisir oleh manusia. ${ }^{2}$

Banyaknya jemaat gereja yang tidak memiliki komitmen terhadap gereja lokal tentu akan berdampak pada pertumbuhan rohani jemaat tersebut. Proses pemuridan dan penggembalaan yang tidak berjalan secara berkesinambungan akan menghambat pertumbuhan rohani jemaat. Pemuridan adalah suatu aspek yang penting dalam kehidupan orang percaya, ketika kita menjadi murid Kristus yang belajar untuk menjadi seperti Sang Guru. Pemuridan adalah suatu perjalanan dan bukan tujuan. Ini berarti bahwa pelayanan yang berdampak kekal dan nyata akan memerlukan waktu untuk berkembang. Pemuridan tidaklah mungkin berupa perbaikan cepat. Murid harus berkomitment untuk jangka panjang. ${ }^{3}$ Bergereja berarti memiliki suatu aturan saling melayani dan saling bertumbuh dalam semua aktivitasnya. Jemaat atau orang Kristen yang sering berpindah-pindah gereja tidak akan memiliki keterlibatan dalam semua proses bergereja dalam suatu

${ }^{2}$ Mimery, Rahasia tentang Penggembalaan (t.k.: Mimery Pressindo Multimedia, t.t.), 15.

${ }^{3}$ www.hikmatpembaharuan.wordpress.com/2012/06/2 6/pemikiran-tentang-pemuridan-beberapa-prinsip-penting/ 
gereja lokal. Dengan kata lain disebut jemaat tanpa komitmen ${ }^{4}$. Rick Warren mengatakan bahwa "Banyak gereja yang kurang menekankan tentang pentingnya mengembangkan komitmen jemaat satu sama lain". 5

Menurut Awi Muliadi Wijaya, penyebab jemaat berpindah gereja dapat dikelompokkan menjadi dua kelompok penyebab, yaitu: Satu, Penyebab alamiah: pindah tempat tinggal (domisili), semakin menua dan sakit-sakitan, meninggal dunia, berbagai keterbatasan lain. Dua, Penyebab lain: masalah/konflik antar jemaat atau pengurus gereja, tidak puas dengan visi-misi gereja, tidak cocok dengan doktrin gereja lokal, tidak puas dengan program gereja lokal, dan tidak puas dengan gaya kepemimpinan gembala, diajak saudara/teman, fasilitas gereja yang kurang nyaman. ${ }^{6}$

Perpindahan jemaat dari suatu gereja ke gereja lain bukanlah suatu hal yang salah selama hal itu dilandasi oleh motivasi yang benar dapat dipertanggung- jawabkan. Hal yang terburuk adalah ketika ada orang yang selalu berpindah-pindah gereja dan tidak pernah menetap di satu gereja. Rasul Paulus (Ef. 4:12) menyatakan bahwa Gereja adalah tubuh Kristus dengan banyak anggota. Setiap anggota tubuh Kristus harus saling melengkapi dan tidak bisa berdiri sendiri.Hal ini membuktikan bahwa anggota tubuh Kristus harus memiliki komitmen untuk bersekutu. Untuk itulah jemaat perlu memiliki komitmen terhadap gereja lokal. Di lain pihak, adalah tugas dari gembala dan jajaran pengurus gereja yang bertanggungjawab untuk menumbuhkan dan memelihara komitmen hidup jemaat bergereja dengan melakukan beberapa hal: menanamkan pengertian tentang komitmen bergereja di gereja lokal. Sehingga ketika jemaat sudah memahami makna dan pentingnya berkomitmen akan membuat jemaat dapat menyatukan diri di dalam gereja lokal. Penelitian terdahulu yang mencoba mengangkat tentang komitment hidup berjemaat adalah oleh Sugianto $(2011)^{7}$ dimana penelitian tersebut adalah berparadigma kualitatif.

Dalam dunia sekuler, komitmen seseorang terhadap organisasi/perusahaan seringkali menjadi isu yang sangat penting. Karena begitu pentingnya hal tersebut, sampaisampai beberapa organisasi sering memakai unsur komitmen sebagai salah satu syarat untuk memegang suatu jabatan/ posisi yang ditawarkan dalam iklan-iklan lowongan pekerjaan. Steers menyebutkan bahwa komitmen yang kuat dapat membawa dampak positif, antara lain: peningkatan prestasi kerja, motivasi kerja, masa kerja, produktifitas kerja, dan karyawan lebih rajin masuk kerja sehingga mengurang absensi dan menurunkan turn over. ${ }^{8}$ Salah satu usaha yang dapat

${ }^{4}$ Robert R. Siahaan, Umat Kristen Tanpa Komitmen, Tabloid Reformata Edisi 153 Juli 2012, Yayasan Pelayanan Media Antiokhia.

${ }^{5}$ Rick Warren, The Purpose Driven Church, Edisi 8

(Gandum Mas), 321

${ }^{6}$ Www.infodokterku.com/component/content/article/28 -info-khusus/info-kristiani-sebelumnya/191-inilah-penyebabjemaat-pindah-gereja.

${ }^{7} \mathrm{http} / / /$ sttaletheia.ac.id/?p=732

${ }^{8}$ R. M. Steers, Motivation and Work Behavior Edisi ke 3 (USA: McGraw Hill Book Company, 1988), 120. dilakukan untuk menanggulangi masalah perpindahan jemaat dari gereja yang satu ke gereja yang lain adalah menumbuhkan dan meningkatkan komitmen jemaat terhadap gereja lokal.

Organisasi tak ubahnya seperti mahluk sosial. "Maka, sebagaimana mahluk sosial selayaknya sukses sebuah organisasi juga tergantung pada rasa saling percaya, substibilitas, dan keintiman para anggotanya. Dan ketiga hal ini bermuara pada komitmen seseorang pada organisasi". Menurut Jenneth dan Linda Schatz. ${ }^{9}$

Menurut Martin dan Nicholls dalam Armstrong, menyatakan bahwa ada tiga pilar untuk membentuk komitmen organisasi seseorang terhadap organisasi, yaitu: Satu, menciptakan rasa kepemilikan terhadap organisasi tersebut, untuk menciptakan kondisi ini orang harus mengidentifikasi dirinya dalam organisasi. Dua, menciptakan semangat dalam bekerja, cara ini dapat dilakukan dengan lebih mengkonsentrasikan pada pengelolaan factor-faktor motivasi intrinsic dan menggunakan berbagai cara perancangan pekerjaan. Tiga, keyakinan dalam manajemen, cara ini mampu dilakukan manakala organisasi benar-benar menunjukkan dan mempertahankan kesuksesan. ${ }^{10}$

Membangun komitmen hidup jemaat dalam bergereja bukan hal yang mudah. Mereka suka tertarik dengan segala fasilitas gereja, acara maupun pelayanan dari beberapa gereja. Sugianto menyatakan bahwa "Motivasi jemaat yang suka berpindah-pindah gereja adalah untuk kesenangan diri sendiri, dan memandang pujian tidak lebih dari sebuah pertunjukan, ada yang sekedar ingin coba-coba, ada yang mencoba mencari gereja yang sesuai dengan keinginannya ,ada yang menganggap semua gereja sama saja, akibatnya jemaat seperti cenderung tidak setia pada gereja"11.

Begitu pentingnya peran kepemimpinan dalam sebuah organisasi menjadi focus yang menarik perhatian para penelti bidang perilaku keorganisasian. Menurut Kartini Kartono, "kepemimpinan merupakan inti dari organisasi dan manajemen"12. Kepemimpinan merupakan faktor penggerak organisasi melalui penanganan dan manajemen yang dilakukan sehingga keberadaan pemimpin bukan hanya sebagai simbol yang ada atau setidaknya tidak menjadi masalah bagi organisasi, tetapi keberadaannya memberikan dampak positif bagi perkembangan organisasi. Alkitab secara khusus memberikan pengakuan kepada kepentingan kepemimpian dengan menegaskan "Jikalau tidak ada pimpinan jatuhlah bangsa, tetapi jika penasehat banyak, kesematan ada" (Ams. 11:14). Di sini Alkitab melihat peran pemimpin dalam kepemimpinan sebagai "sangat

${ }^{9}$ www.rajaprestasi.com/2009/05/menumbuhjankomitmen-dan-motivasi-pada-karyawan/

${ }^{10}$ M. Amstrong, A Handbook of Human Resource Management, Terjemahan (Jakarta: Elex Media Komputindo, 1994), t.h.

${ }^{11}$ Sugianto, Membangun Komitmen Hidup Jemaat Dalam Gereja (Lawang: STTIA, 2011), t.h.

12 Kartono Kartini, Pemimpin dan Kepemimpinan

(Jakarta : PT. Raja Grafindo Persada, 2005), 12. 
penting," karena menentukan jatuh bangunnya suatu kelompok/organisasi.

Menurut Yakob Tomatala, kepemimpinan gereja adalah juga "Suatu proses terencana yang dinamis dalam konteks pelayanan Kristen (yang menyangkut faktor waktu, tempat, dan situasi khusus) yang di dalamnya oleh campur tangan Allah, Ia memanggil bagi diri-Nya seorang pemimpin (dengan kapasitas penuh) untuk memimpin umat-Nya (yang mengelompokkan diri dalam suatu institusi/organisasi gereja) guna mencapai tujuan Allah (yang membawa keuntungan bagi pemimpin, bawahan, dan lingkungan hidup) bagi serta melalui umatNya, untuk kejayaan kerajaan-Nya." ${ }^{13}$ Lebih lanjut ia mengatakan bahwa "Pemimpin gereja adalah pemimpin rohani. Sebagai pemimpin rohani, pemimpin gereja secara khusus terpanggil sebagai gembala." 14

Kristus adalah Gembala Agung dari gereja, namun demikian Ia juga menggunakan manusia sebagai gembala-gembala. Kepemimpinan sebagai gembala adalah kepemimpinan yang mengambil dasar pemahaman atas apa yang di nyatakan oleh Yesus sendiri dengan mengatakan: "Akulah gembala yang baik." Istilah Gembala berasal dari bahasa Inggris Shepherd yang berarti domba sedangkan Ibrani kuno ra'ah artinya memberi makan sehingga gembala dikenal sebagai orang yang memberi makan. Dalam hal ini dapat ditujukan kepada individu yang membantu atau memelihara orang lain dengan memperlihatkan kepedulian yang penuh kasih sayang.

Peter Wagner berpendapat "Tanda penting Nomor Satu dari gereja yang sehat dan bertumbuh adalah pelayan Tuhan (gembala) yang menganut cara berpikir serba mungkin dan yang kepemimpinan dinamisnya digunakan untuk mempengaruhi seluruh gereja supaya bekerja bagi pertumbuhan." 15

Dalam kajian soal kepemimpinan di gereja, menurut Daniel Ronda, "para pemimpin gereja saat ini banyak dikeluhkan soal kepemimpinan yang bukan memimpin dengan hati gembala (herding leadership) melainkan memimpin dengan gaya "herder" (analogi anjing jenis herder). Masalah ini banyak terjadi di dalam gereja atau insitusi di mana banyak pemimpin yang putus asa terhadap pengaplikasian prinsip kepemimpinan dan memilih jalan pintas yaitu dengan cara "herder" yaitu gaya otokratik dan bahkan kekerasan."16

Hal ini diperkuat Sonny Eli Zaluchu yang dalam tulisannya tentang Intrik di Dalam Gereja mengatakan bahwa, "Kelemahan kepemimpinan gembala biasanya ditandai dengan sejumlah aktifitas yang cenderung memaksakan kehendak, gaya penggembalaan yang tidak berkenan, mulut yang tidak terkontrol, menguatnya pengaruh dan intervensi orang-orang tertentu di dalam keputusan gembala (orang kuat, anak, menantu), visi yang

${ }^{13}$ Yakob Tomatala, Kepemimpinan Kristen (t.k.: t.p., 2002), 7-20.

${ }^{14} \mathrm{Ibid}, 15$.

15 Peter C. Wagner, Gereja Saudara dapat Bertumbuh (Malang: Gandum Mas, 2003), 59.

${ }^{16} \mathrm{http} / / / \mathrm{www}$. danielronda.com/index.php/kepemimpin an/55-kajian-atas-kepemimpinan-model-gembala-.html lemah, doa yang kurang dan sikap yang mencerminkan kekunoan (seperti plin-plan, tidak mau mengakui kesalahan dan sikap tidak mau tahu)." ${ }^{17}$ Menurut Robert J. Steven. Orang hanya digerakkan oleh visi, nilai-nilai, prinsip-prinsip dan keyakinan tentang $\operatorname{diri}^{18}$. Hal ini diperkuat juga oleh tokoh kepemimpinan Anthony D'Souza, yang mengatakan tentang kepemimpinan gembala sebagai berikut: "Bagi pemimpin-gembala, produknya adalah para pengikut. Bukan keuntungan , bukan pangsa pasar. Para pengikut itu sendiri yang menjadi tujuan dan produk dari upaya pemimpingembala. Dan, karena itu, ketika dombanya tetap hidup menghadapi berbagai bahaya dalam perjalanan, ketika mereka bertambah kuat, gembala dengan setia menunaikan tugasnya. Domba memang harus dibimbing, didorong, dan dimotivasi untuk mencapai kinerja terbaik. Namun, domba-domba inilah yang memenuhi pemimpin-gembala ketika tidur di malam hari dan yang pertama dicari ketika sinar mentari pagi menandai setiap hari baru. Gembala benar-benar merupakan pelayan domba-dombanya. Pertumbuhan dan pemeliharaan terhadap mereka menjadi tugas dan agendanya dalam mencapai sukses." 19

Organisasi akan berjalan dengan baik jika pimpinan mempunyai kecakapan dalam bidang kepemimpinan khususnya dalam gaya kempimpinannya. Pemimpin harus dapat mempengaruhi orang lain (jemaat) untuk dapat mengikuti kehendaknya dalam rangka mentaati Firman Allah. Dalam setiap situasi yang berbeda pemimpin harus bisa menyesuaikan tindakannya sesuai dengan situasi yang ada. Dengan demikian jemaat akan merasa nyaman dan aman berada di dalam pimpinannya. Jemaat yang merasa tepat berada dibawah kepemimpinnan seorag gembala akan merasa nyaman dan tepat juga untuk berada di gereja tersebut sebagai anggota jemaat.

Dalam Mazmur 23, kita banyak belajar bukan hanya tentang sifat Allah tetapi juga kepemimpinan-Nya. Baik Perjanjian Baru maupun Perjanjian Lama menggunakan istilah "gembala" untuk menggambarkan kepemimpinan. Menurut D'Souza kepemimpinan yang ditampilkan Yesus Kristus memberikan tiga gambaran kepemimpinan transformasional yang menarik, yakni sebagai Pelayan (Servant), Gembala (Shepherd) dan Pengurus (Steward). ${ }^{20}$ Pola atau gaya kepemimpinan seorang pemimpin sangat dipengaruhi oleh jenis organisasinya atau lembaga yang dipimpinnya juga oleh visi, misi organisasi tersebut. Seorang pemimpinan itu

\footnotetext{
${ }^{17}$ Sonny Eli Zaluchu, Intrik dalam Gereja.

http://www.glorianet.org/kolom/ kolointr.html; Gloria Cyber Ministries.

${ }^{18}$ Robert J. Stevens, Management Versus Leadership. 28 Februari 2006.

http://herdingcats.typepad.com/my_weblog/2006/02/managem ent_vers.html.

${ }^{19}$ Anthony D'Souza, Proactive Visionary Leadership

(Jakarta: Trisewu, 2007), 23.

${ }^{20}$ Ibid.
} 
bijaksana atau tidak, sangat tampak dari pilihan gaya kepemimpinan. ${ }^{21}$

Berbicara tentang gaya kepemimpinan maka setiap pemimpin, entah dalam masyarakat atau gereja, pasti memberlakukan suatu gaya dalam kepemimpinannya. Pengertian gaya kepemimpinan yang demikian ini sesuai dengan pendapat yang disampaikan oleh Davis dan Newstrom. ${ }^{22}$ Keduanya menyatakan bahwa pola tindakan pemimpin secara keseluruhan seperti yang dipersepsikan atau diacu oleh bawahan tersebut dikenal sebagai gaya kepemimpinan

Dalam penelitian ini variabel independen kedua setelah gaya kepemimpinan adalah ketrampilan komunikasi. Organisasi tidak mungkin berada tanpa komunikasi. Apabila tidak ada komunikasi, para pegawai tidak dapat mengetahui apa yang dilakukan rekan sekerjanya, pimpinan tidak dapat menerima masukan informasi, dan para penyedia tidak dapat memberikan instruksi, koordinasi kerja tidak mungkin dilakukan, dan organisasi akan runtuh karena ketiadaan komunikasi .23

Ketrampilan Komunikasi dalam gereja sangat penting karena dengan adanya komunikasi maka seseorang bisa berhubungan dengan orang lain dan saling bertukar pikiran yang bisa menambah wawasan seseorang dalam Firman Tuhan atau pelaksanaan dalam kehidupan sehari-hari. Maka untuk membina gembalan dan jemaat maupun hubungan antar jemaat maupun antar atasan bawahan dalam structural organisasi gereja, perlu memiliki ketrampilan komunikasi.

Penelitian sebelumnya yang menghubungkan ketrampilan komunikasi dengan berbagai hasil organisasi antara lain mobilitas pekerjaan, tingkat pekerjaan, gaji, ketrampilan mendengarkan ${ }^{24}$ dan kemampuan mental ${ }^{25}$ serta kemampuan komunikasi kognitif. ${ }^{26}$ Meskipun telah banyak peneliti yang mengkaji kompetensi komunikasi atu ketrampilan komunikasi dalam organisasi, namun belum ada yang meneliti hal tersebut di dalam konteks organisasi gereja. Oleh sebab itu penulis tertarik untuk melakukan penelitian kemampuan komunikasi ini dalam organisasi gereja.

Variabel independen ketiga dalam penelitian ini adalah kotbah. "Pesan kotbah masih merupakan unsur yang terpenting dari kebaktian bagi orang yang belum

${ }^{21}$ Igantius Suharyo, Yang Terpilih untuk Dipecah dan Dibagi (Yogyakarta: Kanisius, 2009), 115.

22 Keith Davis \& John W. Newstrom, Perilaku Dalam Organisasi. Edisi Ketujuh. Terjemahan. (Jakarta: Erlangga, 1995), 180.

${ }^{23}$ Newstrom, Perilaku Dalam Organisasi, 151.

${ }^{24}$ L. O. Cooper, Listening Competency in the Workplace: A Model for Training (t.k.: Business Communication Quarterly, 1997), 60, 75-85.

${ }^{25}$ G. R. Ferris, Witt, L. A., dan Hochwarter, W. A., The Interaction Of Social Skill And General Mental Ability On Work Outcomes. Journal of Applied Psychology, 2001, 86, 1075-1082.

${ }^{26}$ R. L. Duran, dan Spitzberg, B. H., Toward The Development And Validation Of A Measure Of Cognitive Communication Competence (t.k.: Communication Quarterly, 1995), 43, 259-86. bergereja."27 Ungkapan ini disampaikan oleh Rick Warren dalam bukunya "The Purpose Driven Chruch." Selanjutnya ia menambahkna bahwa "Pertumbuhan Saddleback selama lima belas tahun, meskipun berkumpul digedung olah raga yang panas, tenda yang bocor, serta tempat parker yang penuh sesak, telah memperlihatkan bahwa orang-orang yang rela bersabar terhadap keadaan yang tidak nyaman serta keterbatasan yang ada bila kotbah itu benar-benar memenuhi kebutuhan mereka." 28

Menurut Ginting ${ }^{29}$ dalam gereja Protestant, pusat ibadah adalah penyampaian Firman Allah yang disebut dengan kotbah. Kotbah yang benar dan baik serta memiliki pengurapan Roh Kudus serta diterima dengan hati yang telah diurapi Roh Kudus akan besar sekali kuasanya dan dapat membuat perubahan bagi setiap orang yang mendengarkan.

Sementara itu banyak juga kotbah-kotbah dalam ibadah gereja protestan yang tidak memiliki kekuatan seperti itu. Kotbah seperti ini tidak mendapat tempat yang tepat didalam hari setiap pendengarnya. Sehingga setelah keluar dari ibdah gereja dan kembali kedalam kehidupan sehari-hari orang sudah melupakannya. Kotbah itu berlalu bergitu saja. Bahkan sering kotbah itu begitu panjang dan bertele-tele namun jemaat tidak bisa menangkap poin yang seharusnya menjadi inti berita yang disampaikan. Pendeta/pengkotbah yang melakukan kotbah yang seperti ini seharusnya lebih jeli didalam tugas pelayanannya tersebut mengingat kotbah adalah bagian utama dalam ibadah Gereja Protestan. Hanny Layantara $^{30}$ dalam diktat "Ilmu Komunikasi" menyatakan bahwa: dewasa ini, kesadaran akan perlunya pendidikan Ilmu Komunikasi dalam mempersiapkan para pengkotbh dan calon hamba Tuhan sangat terasa. Para lulusan sekolah-sekolah Theologia merasakan adanya kepincangan-kepincangan dalam pelayanan mereka. Walaupun mereka telah menjadi sarjana $\mathrm{S} 1$ dan S2, namun kotbahnya kadang-kadang masih sulit dimengerti, kadang tidak "mengena" atau kurang "menggigit" dan bahkan menimbulkan respon yang salah bagi pendengar.

Kotbah harus mengena dengan pendengarnya. Firman Allah yang disampaikan harus menjadi nafas kehidupan dan membuat perubahan bagi pendengarnya. Kotbah-kotbah yang luar biasa tidak dihasilkan dengan tanpa persiapan atau dengan persiapan yang biasa-biasa saja dan terutama juga tidak dihasilkan tanpa kuasa Roh Kudus.

Peranan Roh Kudus sangat dominan dalam menghasilkan kotbah yang benar dan baik dan berkuasa. Untuk itu persiapan kotbah harus diawali dari diri pengkotbah itu sendiri terpebih dahulu. Pengkotbah harus mengenal Kristus sebagai Tuhan dan juruselamat

${ }^{27}$ Rick Warren, Th ePurpose Driven Church. Cetakan ke-1 (t.k.: Yayasan Gandum Mas, 1999), 313.

${ }^{28}$ Ibid, 313.

${ }^{29}$ Ginting, Kotbah dan Pengkotbah (t.k.: t.p., t.t.), 21.

${ }^{30}$ Hanny Layantara, "Ilmu Komunikasi”. Diktat

STTII Surabaya, 2006. 17. 
hanya Yesuslah jalan keselamatan dan hidup bagi pengkotbah.

Fenomena yang terjadi di banyak jemaat adalah bahwa jemaat jauh-jauh datang dari rumah mereka untuk mencari makanan yang menyegarkan mereka namun setelah tiba di gereja mereka hanya mendapatkan rumput kering yang tentunya tidak enak dimakan. Kotbah yang baik adalah kotbah yang sesuai dengan kebutuhan dombadomba. Makanan bayi tentunya tidak sama dengan makanan untuk orang dewasa. Hanya gembala yang baik yang mengerti kotbah yang bagaimana untuk jemaatnya yang dibutuhkan saat ini.

Rick Warren mengatakan bahwa "Pertumbuhan gereja merupakan akibat wajar dari gereja yang sehat. Gereja yang sehat hanya dapat terjadi bila kotbahnya itu alkitabiah dan misinya seimbang. ${ }^{" 31}$ Kotbah yang baik juga tidak berbelit-belit. Gembala yang tahu benar keadaan dombanya tentu akan memberi makanan yang sederhana kepada domba-dombanya. Noor Anggraito dalam bukunya menyiapkan kotbah ekspositori secara praktis mengatakan bahwa "Apa yang dibutuhkan umat saat ini? Tentunya adalah kebutuhan-kebutuhan rohani yang menyebabkan umat dapat semakin bertumbuh dewasa dan sehat. Barangkali kebutuhan itu berupa pemahaman doktrin yang benar atau praktik perilaku kehidupan dalam berkeluarga, bekerja, ataupun melayani ${ }^{32}$."

Berkotbah yang mengubah hidup adalah dengan mempertemukan kebenaran Firman Allah dan kebutuhankebutuhan yang nyata dari orang-orang melalui penerapan. Hal inilah yang menjadikan jemaat ingin selalu datang ke gereja karena ada kebutuhan yang ingin dipenuhi disana.

\section{RUMUSAN MASALAH}

Pertama, apakah ada pengaruh faktor gaya kepemimpinan, ketrampilan komunikasi dan kotbah, berpengaruh terhadap komitment organisasi jemaat GKI Dasa Surabaya. Kedua, seberapa besar gaya kepemimpinan, ketrampilan komunikasi dan kotbah mempengaruhi komitmen jemaat bergereja di GKI Dasa Surabaya.

\section{TUJUAN PENULISAN}

Yang menjadi tujuan penulisan tesis ini adalah: Tujuan pertama, untuk mengkaji dan memberikan bukti empiris tentang ada tidaknya pengaruh gaya kepemimpinan, ketrampilan komunikasi dam kotbah terhadap komitmen organisasi jemaat di GKI Dasa Surabaya.

Tujuan kedua, untuk mengkaji dan memberikan bukti empiris tentang seberapa besar pengaruh masing-

${ }^{31}$ Warren, The PurposeDriven Church, 55.

${ }^{32}$ Noor Anggarito, Menyiapkan Kotbah Ekspositori Secara Praktis (Yogyakarta: Andi, 2008), 43. masing variabel tersebut diatas terhadap komitment organisasi pada jemaat di GKI Dasa Surabaya.

\section{Kerangka konseptual Penelitian}

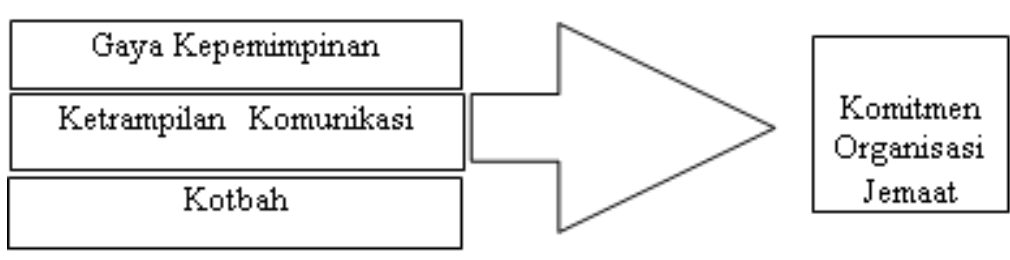

\section{Kerangka Konseptual Penelitian}

Dalam penelitian ini variabel-variable yang akan di analisi dalam pengujian hipotesa adalah sebagai berikut: $\mathrm{X} 1=$ Gaya Kepemimpinan; $\mathrm{X} 2$ = Ketrampilan Komunikasi; X3 = Kotbah; $\mathrm{Y}=$ Komitmen Organisasi Jemaat.

\section{KOMITMENT ORGANISASI}

\section{Pengertian Komitmen Organisasi}

Komitmen Organisasi dapat diartikan sebagai suatu sikap yang harus dimiliki oleh setiap pegawai untuk menunjukkan loyalitas terhadap organisasi dimana mereka bekerja. ${ }^{33}$ Komitmen Organisasi berkaitan erat dengan dengan aspek-aspek psikologis dalam penerimaan dan kepercayaan terhadap nilai-nilai serta tujuan organisasi yang muncul melalui keinginan untuk mempertahankan keanggotaan dalam organisasi tersebut. Untuk memiliki loyalitas anggota dan berkomitmen tinggi, maka diperlukan lingkungan organisasi yang yang tepat, anggota mengenal betul visi, misi, tujuan, sasaran nilai, serta komitmen organisasi tersebut. Menurut Luthan ${ }^{34}$ Komitment Organisasi dapat di definisikan ke dalam tiga pengertian, yakni: Satu, suatu kekuatan sikap sekaligus keputusan untuk menjadi bagian dari organisasi, Dua, suatu keinginan atau kehendak untuk mewujudkan konerja tinggi sebagai bagian yang harus di tumbuhkembangkan dalam organisasi, dan tiga, sebagai suatu keyakinan yang diterima sebagai suatu nilai sekaligus tujuan yang harus dicapai oleh organisasi.

Menurut Greenberg dan Baron, ${ }^{35}$ Komitmen Organisasi menggambarkan seberapa jauh seseorang itu mengidentifikasi dan melibatkan dirinya paa organisasi dan keinginan untuk tetap tinggal di dalam organisasi itu. Menurut Steers ${ }^{36}$ Komitmen Organisasi sebagai kekuatan yang bersifat relative dari individu dalam

\footnotetext{
${ }^{33}$ Djuwita, Forum Manajemen Strategis dan

Pengembangan SDM (t.k.: t.p., 2008).

${ }^{34}$ Fred Luthan, Organizational Behavior (New York: Mc Graw-Hill Comp., 2002), 322.

${ }^{35}$ R. A. Baron, dan J. Greenberg, Behavioral in Organization. Edisi ketiga. Understanding and Managing the Human Side Work (t.k.: t.p., 1990), 309.

${ }^{36}$ R. M. Steers, Motivation and Work Behavior. Edisi ketiga. (USA: McGraw Hill Book Company, 1988), 124.
} 
mengidentifikasikan keterlibatan dirinya ke dalam bagian organisasi. Sikap ini ditandai oleh tga hal, yaitu: satu, bepercayaan yang kuat dan penerimaan terhadap nilainilai dan tujuan organisasi; Dua, kesediaan untuk sungguh-sungguh berusaha atas nama organisasi; Tiga, keinginan yang kuat untuk mempertahankan keanggotaan di dalam organisasi. Menurut Stephen $\mathrm{P}$ Robbin $^{37}$ Komitmen Organisasi adalah suatu sikap kerja yang merefleksikan perasaan seseorang terhadap organisasi yang mencakup loyalitas, identifikasi, dan keterlibatan.

Dapatlah disarikan bahwa Komitmen Organisasi memiliki penekanan proses yang dialami anggota dalam mengidentifikasikan dirinya dengan nilai-nilai, aturanaturan, dan tujuan organisasi. Komitmen Organisasi mengandung pengertian sebagai suatu yang lebih dari sekedar kesetiaan yang pasif terhadap organisasi. Dengan kata lain Komitmen Organisasi menyiratkan hubungan antara anggota dengan organsasi secara aktif.

Menurut Djuwita ${ }^{38}$ Komitmen Organisasi tidak terbatas pada pimpinan yang memangku jabatan fungsional maupun structural, melainkan kepada seluruh anggota dalam organisasi. Komitmen Organisasi dan komitmen setiap anggota dalam organisasi dapat dipengaruhi oleh karakteristik organisasi, sebab anggota yang mempunyai kinerja yang tinggi akan semakin berkembang jika bekerja pada lingkungan organisasi yang memiliki komitmen kerja tinggi yang didukung oleh semangat anggota yang lain.

Menurut Manthis-John H Jackson ${ }^{39}$ Komitmen Organisasi adalah tingkat sampai dimana karyawan yakin dan menerima tujuan organisasi, serta berkeinginan untuk tinggal bersama atau meninggalkan perusahaan yang pada akhirnya tercermin dalam ketidak hadiran dan angka Turn Over karyawan.

Menurut Griffin ${ }^{40}$ Komitmen Organisasi adalah sikap yang mencerminkan sejauh mana seseorang individu mengenal dan terikat pada organisasinya. Seseorang individu yang memiliki komitmen tinggi kemungkinan akan melihat dirinya sebagai anggota sejati organisasi. Cut Zurnali ${ }^{41}$ mendefinisikan Komitmen Organsisasi sebagai sebuah keadaan psikologi yang mengkarakteristikkan hubungan karyawan dengan organisasi atai implikasinya yang mempengaruhi apakah karyawan akan tetap bertahan dalam organisasi atau tidak, yang teridentifikasikan dalam tiga komponen yaitu:

${ }^{37}$ Stephen Robbin, dan Anthony A Judge, Perilaku Organisasi. Edisi 12. Buku 1. (Jakarta: Salemba Empat, 2008), 180.

${ }^{38}$ Djuwita, Forum Manajemen Strategis, 2.

${ }^{39}$ Manthis, dan Jackson, Manajemen Sumber Daya Manusia. Edisi Pertama. Cetakan Pertama (Yogyakarta: Salemba Empat, 2002), 180.

${ }^{40}$ Ricky W. Griffin, Manajemen. Edisi ke 7. Jilid 2. Penerjemah: Gina Gania (Jakarta: Penerbit Erlangga, 2004), 203.

${ }^{41}$ Cut Zurnali, "Learning Organization, Competency, Organizational Commitment, dan Customer Orientation: Knowledge Worker - Kerangka Riset Manajemen Sumber Daya Manusia di Masa Depan,” (Bandung: Unpad Press, 2010), 122. komitmen afektif, komitmen kontinyu dan komitmen normatif.

Definisi Komitmen Organisasi ini menarik dikarenakan yang dilihat adalah sebuah keadaan psikologi karyawan untuk tetap bertahan dalam organisasi. Hal ini di rasa sangat sesuai untuk menganalisis komitmen organisasi para anggota dalam organisasi yang berorientasi nirlaba.

\section{Dimensi Komitmen Organisasi}

Dimensi Komitmen Organisasi menurut Meyer dan Allen sebagaimana ditulis dalam Djuwita ${ }^{42}$ memiliki tiga komponen Pokok yaitu: Satu, Affective Commitment, termasuk di dalamnya hubungan emosional pegawai dengan organisasi dan keterlibatan diri dalam organisasi. Dua, Continuance commitment, termasuk didalamnya hal-hal yang melandasi loyalitas pegawai terhadap organisasi. Tiga, Normatif Commitment, yaitu perasaan pegawai tentang kewajiban yang harus ia berikan kepada organisasi.

Menurut O'Reilly dan Chapman yang dikutip Djuwita mendefinisikan Komitmen Organisasi berdasarkan tiga kriteria, yaitu: Satu, Compliance, yang menunjukkan keterikatan secara instrumental kepada penghargaan ekstrinsik tertentu. Dua, Identification, menunjukkan keterikatan berdasarkan keinginan untuk berafiliasi dengan organsisasi. Tiga, Internalization, menunjukkan keterlibatan karena kesesuaian antara nilainilai individu dengan organisasi.

Jaros dalam Djuwita ${ }^{43}$ membedakan Komitemen Organisasi dalam tiga dimensi, yaitu: Satu, Affective, yaitu tingkat keterikatan secara psikologis dari individu untuk menjadi pegawai dalam organsasi. Dua, Continuance, yaitu perasaan individu karena tingginya resiko yang akan dihadapi bila meninggalkan organisasi. Tiga, Moral yaitu tingkat dimana individu terikat secara psikologis untuk tujuan menjadi pegawai di organisasi melalui internalisasi terhadap tujuan-tujuan, nilai-nilai dan misi.

Berdasarkan teori yang dikemukakan di atas, pada dasarnya komitmen organisasi berkaitan dengan aspek psikologis dalam penerimaan dan kepercayaan terhadap niai-nilai dan tujuan organisasi sehingga dapat ditampilkan melalui kesetiaan serta keinginan untuk terus menjadi anggota organisasi.

Mowday dalam Cut Zurnali ${ }^{44}$ mengemukakan bahwa komitmen telah didefinisikan sebagai kekuatan identifikasi individu yang berada dalam sebuah organisasi. Konsep ini dapat dipecah menjadi tiga komponen yaitu: Satu, keinginan memelihara keanggotaan dalam organisasi; Dua, keyakinan dan penerimaan terhdap nilai dan tujuan organisasi; Tiga, Kesediaan bekerja keras sebagai bagian dari organisasi.

\footnotetext{
${ }^{42}$ Djuwita, Forum Manajemen Strategis, 2

${ }^{43}$ Ibid, 3.

${ }^{44}$ Zurnali, Learning Organization, 124.
} 
Menurut Porter ${ }^{45}$ bahwa telah dikembangkan tiga bagian dari definisi komitmen organisasional yaitu: Satu, Keyakinan dan penerimaan yang kuat dari nilai dan tujuan organisaasi; Dua, Kesediaan untuk bekerja keras sebagai bagian dari organisasi; Tiga, Keinginan yang kuat untuk mengungat organisasi.

Menurut Newstrom dan Davis ${ }^{46}$ komitmen organisasi merupakan tingkat dimana individu memihak dan ingin kontinyu berpartisipasi aktif dalam organisasi, yang tercermin melalui karakteristik-karakteristik sebagai berikut: Satu, Adanya keyakinan yang kuat dan penerimaan atas nilai dan tujuan organisasi; Dua, Kesediaan untuk mengusahakan yang terbaik bagi organisasi; Tiga, Adanya keinginan yang pasti untuk bertahan dalam organisasi.

\section{Pengukuran Komitmen Organisasi}

Berdasarkan tipologi komitmen organisasi yang dikemukakan oleh berbagai tokoh seperti diatas, ada berbagai pengukuran komitmen pada organisasi. Salah satu pengukuran komitmen organisasi yang terkenal adalah Organizational Commitment Questionaire (OQC) yang dibuat oleh Porter dan Smith tahun 1970. Kuisioner ini mengukur komitment afektif melalui 15 pertanyaan yang berbentuk skala Likert tang terdiri dari 7 angka, mulai dari sangat tidak setuju sampai sangat setuju terhadap pernyataan.

Untuk mengukur komitmen organisasi yang terdiri dari tiga komponen (affective, continuance, normative), Allen dan Meyer telah beberapa kali merevisi alat ukur yang telah disusun. Revisi terakhir dilakukan Meyer dan Allen pada tahun 1997. Skala komitmen organisasi ini memiliki skor yang berkisar nilai 1 (sangat tidak setujudengan pernyataan) sampai nilai 6 (sangat setuju dengan pernyataan).

Di dalam penelitian ini akan menggunakan alat ukur yang sama dengan yang di buat oleh Meyer dan Allen dalam revisi yang terakhirnya. Perbedaannya adalah alat ukur yang digunakan dalam penelitian ini menggunakan skala Likert dengan skor berkisar dari nilai 1 (sangat tidak setujudengan pernyataan) sampai nilai 5 (sangat setuju dengan pernyataan).

Definisi Operasional Variabel Komitmen OrganisasiBerdasarkan uraian teori diatas maka definisi operasional variabel Komitmen Organisasi adalah keinginan anggota organisasi untuk tetap mempertahankan keanggotaannya dalam organisasi dan bersedia berusaha keras bagi pencapaian tujuan organisasi.

\section{Konstruk Variabel Komitmen Organisasi}

Konstruk variabel Komitmen Organisasi ${ }^{47}$

\begin{tabular}{|c|c|c|}
\hline \multirow{3}{*}{$\begin{array}{l}\text { Komitmen } \\
\text { Organisasi }\end{array}$} & $\begin{array}{c}\text { Komitmen } \\
\text { afektif }\end{array}$ & $\begin{array}{c}\text { Rasa memiliki } \\
\text { Terikat secara } \\
\text { emosional } \\
\text { Bagian dr organisasi } \\
\text { Bangga pd organisasi } \\
\text { Setia di organsisasi } \\
\end{array}$ \\
\hline & $\begin{array}{l}\text { Komitmen } \\
\text { kontinuen }\end{array}$ & $\begin{array}{c}\text { Sudah berbuat banyak } \\
\text { utk organisasi } \\
\text { Membutuhkan } \\
\text { organisasi } \\
\text { Paling menguntungkan } \\
\text { dr yg lain } \\
\text { Risiko utk pindah } \\
\text { sangat besar } \\
\text { Pilihan yang terbaik } \\
\end{array}$ \\
\hline & $\begin{array}{c}\text { Komitmen } \\
\text { normatif }\end{array}$ & $\begin{array}{c}\text { Tidak etis } \\
\text { meninggalkan } \\
\text { organisasi } \\
\text { Tidak ada alasan } \\
\text { meninggalkan org } \\
\text { Rasa tidak nyaman } \\
\text { meninggalkan org. } \\
\text { Loyalitas kepada } \\
\text { organisasi } \\
\text { Rasa tanggung jawab } \\
\text { pada tugas }\end{array}$ \\
\hline
\end{tabular}

\section{Perumusan Hipotesa}

Berdasarkan uraian Landasan Teori diatas, maka menulis merumuskan hipotesis pertama sebagai berikut: H1: Ada pengaruh secara bersama antara gaya kepemimpinan, ketrampilan komunikasi dan kotbah terhadap komitmen organisasi jemaat bergereja.

\section{GAYA KEPEMIMPINAN}

\section{Pengertian Gaya Kepemimpinan}

Gaya Kepemimpinan mengandung pola perilaku dari seorang yang mencoba memengaruhi orang lain. ${ }^{48}$ Gaya kepemimpinan pada dasarnya mengandung pengertian sebagai suatu perwujudan tingkah laku dari seorang pemimpin yang menyangkut kemampuannya dalam memimpin. Perwujudan tersebut biasanya membentuk suatu pola atau bentuk tertentu.

Pengertian gaya kepemimpinan yang demikian ini sesuai dengan pendapat yang disampaikan oleh Davis dan

\footnotetext{
${ }^{47}$ Meyer, dan Allen, Ommitment in Work Place: Theory, Research, and Application" (t.k.: Sage Publications, 1997), 118.
}

${ }^{45}$ Ibid, 245.

${ }^{46}$ Ibid, 246. 
Newstrom ${ }^{49}$ yang menyatakan bahwa pola tindakan pemimpin secara keseluruhan seperti yang dipersepsikan atau diacu oleh bawahan. Gaya kepemimpinan mewakili filsafat, ketrampilan, dan sikap pemimpin dalam politik. Gaya kepemimpinan adalah pola tingkah laku yang dirancang untuk mengintegrasikan tujuan organisasi dengan tujuan individu untuk mencapai tujuan tertentu. ${ }^{50}$ Sedangkan menurut Tjiptono, ${ }^{51}$ gaya kepemimpinan adalah suatu cara yang digunakan pemimpin dalam berinteraksi dengan bawahannya.

Pendapat lain menyebutkan bahwa gaya kepemimpinan adalah pola tingkah laku (kata-kata dan tindakan-tindakan) dari seorang pemimpin yang dirasakan oleh orang lain. ${ }^{52}$ Hal itu mencakup perilaku perintah (tugas) dan perilaku pemberi dukungan (hubungan). Perilaku perintah membantu anggota kelompok mencapai tujuan dengan memberi perintah, mencapai tujuan dan metode evaluasi, menetapkan tengat waktu, menetapkan peran, dan menunjukkan cara mencapai tujuan. Perilaku perintah menjelaskan, sering kali dengan komunikasi satu arah, apa yang perlu dilakukan, bagaimana hal itu dilaksanakan, dan siapa yang bertanggung jawab melakukan itu. Perilaku pemberi dukungan membantu anggota kelompok merasa nyaman tentang diri mereka, rekan kerja mereka, serta situasi.

Perilaku pendukung melibatkan komunikasi dua arah dan merespon yang menunjukkan dukungan social serta emosional kepada orangn lain. Contoh dari perilaku pemberian dukungan mencakup permintaan akan masukan, pemecahan masalah, pujian, pemberian informasi tentang diri sendiri, dan aktivitas mendengarkan. Perlikau pemberian dukungan terutama terkait dengan pekerjaan.

Menurut William H.Newman (1968) dalam Miftah Thoha $^{53}$ kepemimpinan adalah kegiatan untuk mempengaruhi perilaku orang lain atau seni mempengaruhi perilaku manusia baik perorangan maupun kelompok. Dan satu hal yang perlu diingat bahwa kepemimpinan tidak harus dibatasi oleh aturan-aturan atau tata karma birokrasi. Kepemimpinan bisa terjadi dimana saja, asalkan seseorang menunjukkan kemampuannya mempengaruhi perilaku orang lain kearah tercapainya suatu tujuan tertentu.

Bahasan mengenai pemimpin dan kepemimpinan pada umumnya menjelaskan bagaimana untuk menjadi pemimpin yang baik, gaya dan sifat yang sesuai dengan kepemimpinan serta syarat-syarat apa yang perlu dimiliki

${ }^{49}$ Keith Davis, dan John W. Newstrom, Perilaku

Dalam Organisasi. Edisi Ketujuh. Terjemahan. (Jakarta: Erlangga, 1995), 180.

${ }^{50}$ Heidjrachman dan Suad Husnan, "Manajemen Personalia.” Cetakan kedua. (Yogyakarta: BPFE, 2002), 224.

${ }^{51}$ Fandy Tjiptono, “Strategi Pemasaran.” Edisi

Kedua. Cetakan Kelima. (Yogyakarta: Andi Offset, 2001), 161.

52 Hersey, "Kunci Sukses Pemimpin Situasional”

(Jakarta: Delaprasata, 2004), 29.

${ }^{53}$ Miftah Thoha, Kepemimpinan dalam Manajemen (Jakarta: Rajawali Pers, 1983), 262. oleh seorang pemimpin yang baik. Meskipun demikian masih tetap sulit untuk menerapkan seluruhnya, sehingga dalam prakteknya hanya beberapa pemimpin saja yang dapat melaksanakan kepemimpinannya dengan baik dan dapat membawa para pengikutnya kepada keadaan yang diinginkan.

Kepemimpinan dapat dikategorikan sebagai ilmu sosial terapan (applied social sciences). Hal ini didasarkan kepada pemikiran bahwa kepemimpinan dengan prinsip-prinsipnya mempunyai manfaat langsung dan tidak langsung terhadap upaya mewujudkan kesejahteraan umat manusia.

Kepemimpinan seperti halnya ilmu-ilmu yang lain, mempunyai berbagai fungsi antara lain, menyajikan berbagai hal yang berkaitan dengan permasalahan dalam kepemimpinan dan memberikan pengaruh dalam menggunakan berbagai pendekatan dalam hubungannya dengan pemecahan aneka macam persoalan yang mungkin timbul dalam ekologi kepemimpinan. Kepemimpinan sebagai salah satu cabang ilmu pengetahuan, yang mempunyai peran penting dalam rangka proses administrasi. Hal ini didasarkan kepada pemikiran bahwa peran seorang pemimpin merupakan implementasi atau penjabaran dari fungsi kepemimpinan. Fungsi kepemimpinan merupakan salah satu di antara peran administrator dalam rangka mempengaruhi orang lain atau para bawahan agar mau dengan senang hati untuk mencapai tujuan organisasi yang telah ditetapkan sebelumnya.

Gaya kepemimpinan, mengandung pengertian sebagai suatu perwujudan tingkah laku dari seorang pemimpin, yang menyangkut kemampuannya dalam memimpin. Perwujudan tersebut biasanya membentuk suatu pola atau bentuk tertentu.Hersey dan Blanchard (1992) berpendapat bahwa gaya kepemimpinan pada dasarnya merupakan perwujudan dari tiga komponen, yaitu pemimpin itu sendiri, bawahan, serta situasi di mana proses kepemimpinan tersebut diwujudkan. Bertolak dari pemikiran tersebut, Hersey dan Blanchard (1992) mengajukan proposisi bahwa gaya kepemimpinan (k) merupakan suatu fungsi dari pimpinan (p), bawahan (b) dan situasi tertentu (s)., yang dapat dinotasikan sebagai : $\mathrm{k}=\mathrm{f}(\mathrm{p}, \mathrm{b}, \mathrm{s})$.Menurut Hersey dan Blanchard, pimpinan (p) adalah seseorang yang dapat mempengaruhi orang lain atau kelompok untuk melakukan unjuk kerja maksimum yang telah ditetapkan sesuai dengan tujuan organisasi.

Organisasi akan berjalan dengan baik jika pimpinan mempunyai kecakapan dalam bidangnya, dan setiap pimpinan mempunyai keterampilan yang berbeda, seperti keterampilan teknis, manusiawi dan konseptual. Sedangkan bawahan adalah seorang atau sekelompok orang yang merupakan anggota dari suatu perkumpulan atau pengikut yang setiap saat siap melaksanakan perintah atau tugas yang telah disepakati bersama guna mencapai tujuan. Dalam suatu organisasi, bawahan mempunyai peranan yang sangat strategis, karena sukses tidaknya seseorang pimpinan bergantung kepada para 
pengikutnya ini. Oleh sebab itu, seorang pemimpinan dituntut untuk memilih bawahan dengan secermat mungkin.

Adapun situasi (s) menurut Hersey dan Blanchard adalah suatu keadaan yang kondusif, di mana seorang pimpinan berusaha pada saat-saat tertentu mempengaruhi perilaku orang lain agar dapat mengikuti kehendaknya dalam rangka mencapai tujuan bersama. Dalam satu situasi misalnya, tindakan pimpinan pada beberapa tahun yang lalu tentunya tidak sama dengan yang dilakukan pada saat sekarang, karena memang situasinya telah berlainan. Dengan demikian, ketiga unsur yang mempengaruhi gaya kepemimpinan tersebut, yaitu pimpinan, bawahan dan situasi merupakan unsur yang saling terkait satu dengan lainnya, dan akan menentukan tingkat keberhasilan kepemimpinan

Ada beberapa jenis gaya kepemimpinan yang ditawarkan oleh para pakar leardership, mulai dari yang klasik sampai kepada gaya kepemimpinan situasional model Hersey dan Blancard.

Ada 7 model gaya pembuatan keputusan yang dilakukan pemimpin. Model pertama, Pemimpin membuat keputusan kemudian mengumumkan kepada bawahannya. Dari model ini terlihat bahwa otoritas yang digunakan atasan terlalu banyak sedangkan daerah kebebasan bawahan terlalu sempit sekali.

Model kedua, Pemimpin menjual keputusan. Dalam hal ini pemimpin masih terlihat banyak menggunakan otoritas yang ada padanya, sehingga persis dengan model yang pertama. Bawahan disini belum banyak terlibat dalam pembuatan keputusan.

Model ketiga, Pemimpin memberikan pemikiranpemikiran atau ide-ide dan mengundang pertanyaanpertanyaan.

Dalam model ini pemimpin sudah menunjukkan kemajuan, karena membatasi penggunaan otoritas dan memberikan kesempatan kepada bawahan untuk mengajukan pertanyaan-pertanyaan. Bawahan sudah sedikit terlibat dalam pembuatan keputusan.Model keempat, Pemimpin memberikan keputusan bersifat bersifat sementara yang kemungkinan dapat diubah. Bawahan sudah mulai banyak terlibat dalam rangka pembuatan keputusan, sementara otoritas pemimpin sudah mulai dikurangi penggunaannya, Model kelima, Pemimpin memberikan persoalan, meminta saran-saran dan membuat keputusan. Disini otoritas pimpinan digunakan sedikit mungkin, sebaliknya kebebasan bawahan dalam berpartisipasi membuat keputusan sudah banyak digunakan.

Model keenam, Pemimpin merumuskan batasbatasnya, dan meminta kelompok bawahan untuk membuat keputusan. Partisipasi bawahan dalam kesempatan ini lebih besar dibandingkan kelima model diatas.Model ketujuh, Pemimpin mengizinkan bawahan melakukan fungsi-fungsinya dalam batas-batas yang telah dirumuskan oleh pimpinan. Model ini terletak pada titik ekstrem penggunaan kebebasan bawahan, adapun titik ekstrem penggunaan otoritas terdapat pada nomor satu di atas. Definisi Operasional Variabel Gaya Kepemimpinan
Berdasarkan uraian teori di atas maka dirumuskan definisi operasional variable Gaya Kepemimpinan adalah kemampuan seseorang untuk mempengaruhi perilaku orang lain menurut keinginan-keinginannya dalam suatu keadaan tertentu untuk mencapai tujuan organisasi.

\section{Konstruk Gaya Kepemimpinan ${ }^{54}$}

\begin{tabular}{|c|c|c|}
\hline \multirow{7}{*}{$\begin{array}{c}\text { Gaya } \\
\text { Kepemimpinan }\end{array}$} & Telling & \begin{tabular}{|c|}
$\begin{array}{c}\text { Pimpinan merumuskan } \\
\text { perananan bawahan dan } \\
\text { model komunikasi satu arah }\end{array}$ \\
Memberitahukan apa, \\
bagaimana, dimana dan \\
kapan waktunya kepada \\
bawahan
\end{tabular} \\
\hline & \multirow[t]{2}{*}{ Selling } & $\begin{array}{c}\text { Pimpinan memberikan } \\
\text { petunjuk bersamaan dengan } \\
\text { dukungan kepada bawahan }\end{array}$ \\
\hline & & $\begin{array}{c}\text { Menggunakan komunikasi } \\
\text { dua arah dan memberi } \\
\text { support untuk penyelesaian } \\
\text { pekerjaan }\end{array}$ \\
\hline & \multirow{2}{*}{ Participating } & $\begin{array}{c}\text { Sharing membuat keputusan } \\
\text { untuk mencapai tujuan }\end{array}$ \\
\hline & & $\begin{array}{l}\text { Pemimpin lebih sedikit } \\
\text { memberikan tugas karena } \\
\text { pertimbangan hubungan }\end{array}$ \\
\hline & \multirow[t]{2}{*}{ Delegating } & $\begin{array}{c}\text { Pemimpin sedikit sekali } \\
\text { terlibat dalam pengambilan } \\
\text { keputusan dan melimpahkan } \\
\text { kepada bawahan }\end{array}$ \\
\hline & & $\begin{array}{c}\text { Pemimpin terlibat dalam } \\
\text { progress pekerjaan untuk } \\
\text { memantau pencapaian yang } \\
\text { ada }\end{array}$ \\
\hline
\end{tabular}

Dalam penelitian ini instrument skala gaya kepemimpinan yang digunakan adalah instrument yang kembangkan oleh Paul Hersey dan Kenneth Blanchard.

\section{Perumusan Hipotesis}

Berdasarkan landasan teori yang telah di jabarkan diatas maka penulis merumuskan hipotesis kedua (H2) sebagai berikut: H2: Ada pengaruh antara gaya kepemimpinan terhadap komitmen organisasi jemaat bergereja.

\section{KETRAMPILAN KOMUNIKASI}

Ketrampilan komunikasi sama dengan kemampuan seseorang dalam berkomunikasi. Meskipun setiap hari orang berkomunikasi, tetapi jarang orang yang tahu sejauh mana efektivitas komunikasi kita, baik secara individual, sosial, maupun secara profesional.

\footnotetext{
${ }^{54}$ Paul Hersey dan Ken Blanchard, "Leader
}

Effectiveness dan Adaptability Description” (t.k.: t.p., 1988), 1-8. 
Jablin dan Sias dalam Payne, $2005{ }^{55}$ mendefinisikan kompetensi komunikasi sebagai sejumlah kemampuan yang dimiliki seorang komunikator untuk digunakan dalam proses komunikasi, yang menekankan pada pengetahuan dan kemampuan.

Kompetensi menurut Spitzberg dan Cupach dalam Jablin dan Putnam ${ }^{56}$ mengatakan "Competence is an issue both perennial and fundamental to the study of communication." Monge, Bachman, Dillard, and Eisenberg dalam Jablin and Putnam ${ }^{57}$ menyamakan kompetensi dengan ke-efektifan dan menyatakan bahwa "competent communicators are those who are effective at achieving their goals" Menurut Park dalam Jablin dan Putnam $^{58}$ secara lebih spesifik lagi menyatakan bahwa: "Communication competence represent the degree to which individual satisfy and perceive that they satisfied their goal within the limits of given social situation without jeopardizing their ability or opportunity to persue other subjectivity more important goals."

Brian Spitzberg dan William Cupach ${ }^{59}$ menyatakan bahwa kompetensi komunikasi merupakan kemampuan seorang individu untuk beradaptasi dan berkomunikasi secara efektif dalam segala situasi sosial sepanjang waktu, dimana kemampuan ini mengarah pada kemampuan untuk bertindak yang dipengaruhi motivasi dan pengetahuan yang dimiliki individu.

Berdasarkan uraian di atas dapat disimpulkan bahwa kompetensi komunikasi adalah kemampuan seorang individu untuk berkomunikasi secara tepat dan efektif sesuai dengan situasi sosialnya, yang meliputi kemampuan individu dalam bertindak, serta pengetahuan dan motivasi yang dimiliki individu.

Menurut Asrori ialah, "Komunikasi verbal, komunikasi fisik, komunikasi emosional."60 Berikut penjelasan tentang keterampilan yang dibutuhkan untuk masing-masing komunikasi tersebut: Satu, Keterampilan komunikasi verbal. Komunikasi verbal adalah komunikasi yang terjadi bila dua orang atau lebih melakukan kontak satu sama lain dengan menggunakan alat artikulasi atau pembicaraan. Prosesnya terjadi dalam bentuk percakapan satu sama lain.

${ }^{55}$ Holly J. Payne, Western Kentucky University, "Reconceptualizing Social Skills in Organizations: Exploring the Relationship between Communication Competence, Job Performance, and Supervisory Roles, ” Journal of Leadership and Organizational Studies, SAGE Journals, Winter 2005, Vol. 11 no. 2, 63-77.

${ }^{56} \mathrm{~F}$. Jablin, dan Linda L. Putnam, Communication competence. In The new handbook of organizational communication: Advances in theory, research, and methods, eds. Thousand Oaks, (CA: Sage, 2001), 219.

${ }^{57}$ Ibid, 820.

58 Ibid, 820 .

${ }^{59}$ Brian Spitzberg, dan William Cupach, Interpersonal Communication Competence (Beverly Hills CA: Sage

Publications, 1984), 105.

${ }^{60}$ M. Asrori, Pengembangan Peserta Didik (Malang: Wineka Media, t.t.), 136.
Asrori mengemukakan bahwa, "Dalam melakukan komunikasi verbal, seseorang harus terampil dalam menggunakan kata-kata, menggunakan tata bahasa yang teratur dan sopan, serta mampu menjadi pendengar yang baik bagi lawan bicara." ${ }^{\prime 61}$

Ini berarti, komunikasi verbal adalah komunikasi yang secara nyata dapat dilihat melalui percakapan antara dua orang atau lebih, sehingga setiap orang yang melakukan komunikasi verbal perlu untuk memiliki kemampuan dalam menggunakan kata-kata, tata bahasa yang baik dan sopan, sehingga pesan yang disampaikan dapat mudah ditangkap oleh penerima pesan (lawan bicara).

Dua, Keterampilan komunikasi fisik. Komunikasi fisik adalah komunikasi yang terjadi manakala dua orang atau lebih melakukan kontak dengan menggunakan bahasa tubuh. Misalnya, ekspresi wajah, posisi tubuh, gerak-gerik dan kontak mata. Asrori mengemukakan bahwa, "Seseorang membutuhkan kemampuan untuk menggunakan isyarat non verbal, seperti ekspresi wajah, lambaian tangan dan lain sebagainya, secara tepat agar pesan dapat diterima oleh penerima pesan"62.

Berarti, dalam menggunakan komunikasi fisik, seseorang diharuskan memiliki kemampuan untuk menggunakan anggota tubuh secara tepat dan sesuai dengan yang disampaikan, agar pesan dapat mudah diterima dan dipahami oleh penerima pesan.

Tiga, Keterampilan komunikasi emosional. Komunikasi emosional adalah interaksi yang terjadi manakala individu melakukan kontak satu sama lain dengan melakukan curahan perasaan. Misalnya, mengeluarkan air mata sebagai tanda sedih, haru, atau bahkan terlalu bahagia.

Asrori mengemukakan bahwa, "Seseorang harus mampu mengontrol mental dan kondisi kejiwaannya agar tetap dalam keadaan stabil." ${ }^{63}$ Berdasarkan pendapat ini, seseorang yang dikatakan terampil melakukan komunikasi emosional adalah apabila dalam melakukannya ia tetap berada pada kondisi mental dan kejiwaan yang stabil, sehingga hal-hal yang bersifat bentuk komunikasi emosinal seperti sedih, haru dan senang tetap terlihat dalam bentuk yang wajar dan tidak berlebihan.

Sedangkan menurut Rowley kompetensi komunikasi adalah kemampuan untuk mengirim pesanpesan yang mendukung pencapaian tujuan dimana tetap menjaga penerimaan sosial. ${ }^{64}$ Definisi kompetensi komunikasi dalam perspektif perilaku dirumuskan oleh Wiemann dan Backlund dalam Jubaedah, ialah kemampuan seorang individu untuk mendemonstrasikan pengetahuan dari perilaku berkomunikasi yang tepat dalam suatu situasi tertentu. ${ }^{65}$ Sedangkan Payne dalam

\footnotetext{
${ }^{61}$ Ibid, 136.

${ }^{62}$ Asrori, Pengembangan Peserta Didik, 137.

${ }^{63}$ Ibid.

${ }^{64} \mathrm{http}: / / \mathrm{www}$.aligningaction.com/comcomp.html.
}

Rowley, Richard D. 2002. Communicatio Competence: The

Essence of Aligning Action.

${ }^{65}$ Edah Jubaedah, Analisis Hubungan Gaya

Kepemimpinan dan Kompetensi Komunikasi dalam 
Jubaedah mendefinisikan kompetensi komunikasi yang dirumuskan oleh Jablin dan Sias yaitu The set of abilities, henceforth, termed resources, which a communicator has available for use in the communication process. ${ }^{66}$

Kompetensi komunikasi diartikan sebagai seperangkat kemampuan seorang komunikator untuk menggunakan berbagai sumber daya yang ada di dalam proses komunikasi. Dengan kata lain, kompetensi komunikasi adalah pengetahuan yang dimiliki pegawai untuk berkomunikasi dengan baik dimana menggunakan pesan-pesan yang dianggap tepat dan efektif.

Alo Liliweri menyatakan bahwa ada empat kompetensi yang diperlukan pegawai demi terciptanya komunikasi yang efektif yaitu: ${ }^{67}$ Kompetensi pegawai untuk menyampaikan semua maksud atau isi hatinya secara professional sesuai dengan kemampuan yang ia tampilkan secara prima.

Kompentensi pegawai untuk berinteraksi secara baik, mampu mengalihbahasakan semua maksud dan isi hatinya secara tepat dan jelas dalam suasana hati yang bersahabat. Kompentensi pegawai untuk menyesuaikan budaya pribadinya dengan budaya yang sedang dihadapinya.

Kompentensi pegawai untuk memberikan fasilitas atau jaminan bahwa dia bisa menyesuiakan diri atau bisa mengelola berbagai tekanan orang ataupun lingkungan lain terhadap dirinya. Keempat aspek tersebut menunjukkan bahwa efektivitas komunikasi tidak hanya ditentukan karena setiap pegawai sudah melakukan interaksi, relasi dan komunikasi sesuai dengan peranan (profesi).

Brian Spitzberg dan William Cupach menyatakan bahwa terdapat tiga komponen kompetensi komunikasi, yaitu: knowledge, skills, dan motivation. ${ }^{68}$ Knowledge. Untuk mencapai tujuan dari komunikasi, individu harus memiliki pengetahuan yang dibutuhkan dalam berkomunikasi secara efektif dan tepat. Spitzberg dan Cupach mengemukakan bahwa pengetahuan dalam hal ini lebih ditekankan pada " bagaimana" sebenarnya komunikasi daripada "apa" itu komunikasi. ${ }^{69}$ Pengetahuan-pengetahuan tersebut diantaranya seperti mengetahui apa yang harus diucapkan, tingkah laku seperti apa yang harus diambil dalam situasi yang berbeda, bagaimana orang lain akan menanggapi dan berperilaku, siapa yang diajak berkomunikasi, serta memahami isi pesan yang disampaikan.

Pengetahuan ini dibutuhkan agar komunikasi dapat berjalan secara efektif dan tepat. Pengetahuan ini akan bertambah seiring tingginya pendidikan dan pengalaman. Oleh karena itu, semakin seseorang mengetahui bagaimana harus berkomunikasi dalam situasi yang

Organisasi. Jurnal Ilmu Administrasi, Volume VI No. 4

Desember 2009. (t.k.: t.p., 2009), 375.

${ }^{66}$ Ibid, 375.

${ }^{67}$ Alo Liliweri, Dasar-dasar Komunikasi Antar

Budaya (Yogyakarta: Pustaka Pelajar. 2004), 101-102.

${ }^{68}$ Brian H. Spitzberg, dan William R. Cupach,

Interpersonal Communication Competence (New York: Sage

Publication, 1984), 220.

${ }^{69}$ Ibid, 222 berbeda maka kompetensi atau kemampuan berkomunikasinya akan semakin baik.

Motivation. Motivasi dalam hal ini merupakan hasrat atau keinginan seseorang untuk melakukan komunikasi atau menghindari komunikasi dengan orang lain $^{70}$. Motivasi biasanya berhubungan dengan tujuantujuan tertentu seperti untuk menjalin hubungan baru, mendapatkan informasi yang diinginkan, terlibat dalam pengambilan keputusan bersama, dan lain sebagainya. Semakin individu memiliki keinginan untuk berkomunikasi secara efektif dan meninggalkan kesan yang baik terhadap orang lain, maka akan semakin tinggi motivasi individu untuk berkomunikasi. Dalam hal ini, tanggapan yang diberikan orang lain akan mempengaruhi keinginan individu dalam berkomunikasi. Jika individu terlalu takut untuk mendapat tanggapan yang tidak dinginkan, maka keinginannya untuk berkomunikasi akan rendah.

Skills. Skill meliputi tindakan nyata dari perilaku, yang merupakan kemampuan seseorang dalam mengolah perilaku yang diperlukan dalam berkomunikasi secara tepat dan efektif. Kemampuan ini meliputi beberapa hal seperti other- orientation, social anxiety, expressiveness, dan interaction management. Other-orientation meliputi tingkah laku yang menunjukkan bahwa individu tertarik dan memperhatikan orang lain. Dalam hal ini, individu mampu mendengar, melihat dan merasakan apa yang disampaikan orang lain baik secara verbal maupun nonverbal ${ }^{71}$. Other-orientation akan berlawanan dengan self-centeredness dimana individu hanya memperhatikan dirinya sendiri dan kurang tertarik dengan orang lain dalam berkomunikasi. Social anxiety meliputi bagaimana kemampuan individu mengatasi kecemasan dalam berbicara dengan orang lain dan menunjukkan ketenangan dan percaya diri dalam berkomunikasi. Expressiveness mengarah pada kemampuan dalam berkomunikasi yang menunjukkan kegembiraan, semangat, serta intensitas dan variabilitas dalam perilaku komunikasi. Hal ini dapat dilihat dari penggunaan vocal yang beragam, wajah yang ekspresif, penggunaan vocabulary yang luas, serta gerak tubuh. Sedangkan interaction management merupakan kemampuan untuk mengelola interaksi dalam berkomunikasi, seperti pergantian dalam berbicara serta pemberian feedback atau respon.

\section{Definisi Operasional Ketrampilan Komunikasi}

Definisi operasional kmampuan komunikasi adalah kemampuan individu yang memili motivasi dan pengetahuan untuk beradaptasi secara efektif dalam segala situasi sosial.
${ }^{70}$ Ibid, 223
${ }^{71}$ Cupach, Interpersonal Communication, 224. 
Konstruk variabel ketrampilan komunikasi ${ }^{72}$

\begin{tabular}{|c|c|c|}
\hline & \multirow{3}{*}{ Knowledge } & $\begin{array}{c}\text { Tentang lawan } \\
\text { bicara / audience }\end{array}$ \\
\hline \multirow{9}{*}{$\begin{array}{l}\text { Ketrampilan } \\
\text { Komunikasi }\end{array}$} & & $\begin{array}{c}\text { Beradaptasi } \\
\text { dengan } \\
\text { lingkungan }\end{array}$ \\
\hline & & Isi pesan \\
\hline & \multirow{4}{*}{ Skill } & Social anxiety \\
\hline & & $\begin{array}{l}\text { Expresi wajah, } \\
\text { body language }\end{array}$ \\
\hline & & $\begin{array}{c}\text { Interaction } \\
\text { management }\end{array}$ \\
\hline & & $\begin{array}{l}\text { Orientasi pada } \\
\text { orang lain }\end{array}$ \\
\hline & \multirow{3}{*}{ Motivation } & Pencapaian tujuan \\
\hline & & $\begin{array}{l}\text { Menjalin } \\
\text { Hubungan }\end{array}$ \\
\hline & & Mencari informasi \\
\hline
\end{tabular}

\section{Perumusan Hipotesa}

Berdasarkan uraian Landasan Teori diatas, maka menulis menrumuskan hipotesis sebagai berikut: H3: Ada pengaruh antara ketrampilan komunikasi dengan komitmen organisasi jemaat bergereja.

\section{КОТВАН}

Mendefinisikan kata kotbah bukanlah hal yang mudah. Pemahaman terhadap kotbah menjadi berbeda di mata sarjana yang berbeda. Selain unsur teologi, unsurunsur lain seperti bahasa, latar belakang dan budaya juga ikut menentukan pemahaman seseorang akan kotbah. ${ }^{73}$

Kamus Besar Bahasa Indonesia melihat kotbah sebagai "pidato (teruatama yang menguraikan ajaran

${ }^{72}$ Brian H. Spitzberg, dan William R. Cupach, "Interpersonal Communication Competence" (t.k.: SAGE Publications, 1984).

${ }^{73}$ Hasan Sutanto, "Homiletik Prinsip dan Metode Berkotbah" (Malang: Literatur SAAT, 2007), 19.

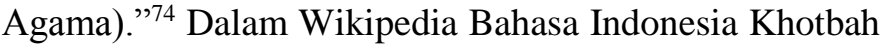
atau kotbah, dari bahasa Arab adalah sebuah presentasi atau pidato yang biasanya berhubungan dengan agama atau dengan moral. ${ }^{75}$

Menurut Webster's New Universal Unbridge Dictionary (Second Edition, 1983) dalam Hasan Sutanto $^{76}$ memberikan pengertian sermon sebagai berikut: Satu, suatu pidato,pembicaraan atau tulisan. Dua, suatu pembicaraan dari mimbar, dengan mengutip suatu bagian dari Alkitab, yang bertujuan menyampaikan ajaran agama atau mengajarkan moralitas; suatu pembicaraan yang mirip yang ditulis atau dicetak, baik disampaikan atau tidak ; suatu homily. Tiga, suatu nasihat, teguran atau kritikan serius; pidato tentang kelakuan atau kewajiban seorang, khususnya yang disampaikan dengan panjang lebar, menjemukan dan mengganggu. Penjelasan ini memberi kesan, kata sermonmengandung arti umum yang sudah terlepas dari arti sempitnya.

Menurut Ginting ${ }^{77}$ mengatakan bahwa kotbah adalah suatu kharisma. Kemampuan berkotbah adalah merupakan pemberian Allah. Yang ditekankan disini bukan kemampuan manusiawi secara kognitif, melainkan kharisma atau pemberian Allah.

Karenanya si pengkotbah tidak boleh berkotbah asalasalan atau semau gue saja. Metode yang betul untuk mengusahakan pengajaran yang bisa dipertanggungjawabkan, harus dipelajari oleh setiap pengkotbah.Martin Luther mengatakan bahwa: ${ }^{78}$ Isi Kotbah adalah Firman. Maksudnya adalah kotbah menjadi sentral dalam gereja Reformasi. Arti berkotbah seturut dengan terminologi tadi adalah menyampaikan firman Allah. Yang berisi pengajaran (kerygma).

Menurut Origenes (185-254), homilitika ialah ilmu (pengetahuan) yang menerangkan dan menjelaskan arti, isi, maksud, dan tujuan Firman Tuhan. Ginting mengatakan bahwa: ${ }^{79}$ Pada jaman Origenes inilah dicari cara atau metode-metode untuk menrangkan atau menjelaskan arti, isi, maksud dan tujuan Firman Tuhan. Dialah yang memelopori metode menerangkan dan metode mengkotbahkan Firman Tuhan secara Somatis, Psikis, dan Pneumatis. Somatis berarti menerangkan Firman Tuhan sesuai dengan tujuan, maksud dan arti yang tertulis. Pengertian secara harafiah itulah Firman Tuhan (Mat. 5:39). Psikis berarti mencari pengertian lain dan lebih luas dari apa yang tertulis dalam nats (Mat. 5:42). Psikis berasal dari $p s u h e(\pi \sigma v \chi \eta)$ yang berarti jiwa. Dalam hal ini kita mengusahakan keterangan kotbah yang lebih luas dan mendalam. Pneumatis $(\pi v \varepsilon v \mu \alpha)$ artinya jauh lebih luas daripada arti psikis. Dari sinilah timbul pengajaran dan pengertian Origenes dengan metode alegoris, yaitu mengatakan yang lain dari pada

${ }^{74}$ Kamus Besar Bahasa Indonesi, Pusat Bahasa,

Dep.Dik. Nas. 2008, 718.

${ }^{75} \mathrm{http} / / \mathrm{www}$.wikipedia.org.

${ }^{76} \mathrm{Ibid}, 20$.

${ }^{77}$ Ibid, 1.

${ }^{78}$ Ginting, Kotbah dan Pengkotbah, 2.

${ }^{79}$ Killinger, Dasar-dasar Kotbah, 9. 


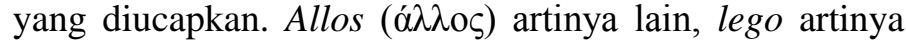
mengatakan. Menurut Agustinus, ${ }^{80}$ kotbah mencakup unsur: Docere (mengajar), delectere (Menyenangkan hati), flectere (menggerakkan hati). "Docere" bersifat pengajaran. "Dolectere" ialah percakapan yang penuh arti. "Flectere" berarti yang menimbulkan rasa cinta, keinginan, kerinduan, akan isi percakapan. Dengan menjelaskan unsur-unsur yang tercakup didalam kotbah diatas, Agustinus merumuskan tujuan kotbah sebagai berikut:

Satu, Pateat: supaya kebenaran semakin luas diketahui. Dua, Placeat: supaya kebenaran diterima dengan gembira. Tiga, Moveat : supaya kebenaran semakin menggerakkan orang, Agustinus dalam kotbahnya tidak memakai ilmu retorika (berpidato) tetapi sermo homilis (kotbah yang bersifat rendah hati; homilis sama dengan sederhana, suatu kotbah dalam bahasa yang sederhana). Kotbahnya sangat provan, ikut hidup dalam pendengarnya supaya tetap waspada terhadap ajaran sesat.

Johanes Chrystosomus seorang pengkotbah ulung pada masanya mengatakan bahwa seseorang yang mempeajari teologi tujuannya adalah mengkotbahkan Firman Tuhan. Karena menurut Chrystosomus menafsirkan firman Tuhan adalah sama dengan berkotbah. Kotbah menurut Chrystosomus adalah: ${ }^{81}$

Mengandung aspek pendidikan, juga membangkitkan roh membangun di jemaat (1 Kor. 3:10 dan 1 Kor. 14:26). Istilah "oikodome" menunjukkan segala aktivitas jemaat yang membangun iman. Karenanya setiap pendengar dituntut untuk turut aktif berpaertisipasi dalam pembangunan jemaat. Kotbah adalah suara dan panggilan Yesus. Kotbah Chrystosomus kebanyakan berisi tafsiran-tafsiran Alkitab dengan aplikasi yang homiletis. Tugas berkotbah bagi Chrystosomus merupakan tugas penggembalaan. Kotbah dan penggembalaan sangat erat hubungannya.

Menurut Andreas Gerard Hyperius ${ }^{82}$ (1511-1564) ada 5 (lima) fungsi kotbah yaitu:

Didaskalin: mengajar, Regardutivum : menantang (arguendum), Institutivum: mendidik (erdiendum), Corriviendum: mengingatkan, menasihatkan (reproof, rebuke), Consolatorium: penghiburan.

Philip Melanchton (1497) memberikan sumbangan dalam bidang Homilitika tentang kebebasan. Manusia dikaruniai Tuhan kesanggupan dan kebebasan. Pendidikan Melanchton dengan latar belakang humanis turut mempengaruhinya. Ia menentang dengan keras kekuasaan Katolik Roma sebagai badan yang berwenang atau berkuasa atas Firman Tuhan (Alkitab). Tahun 1539 Melanchton menulis buku berjudul De eccleia et de autoriatate verbi dei ( Tentang hukum Gereja dan Tentang Penguasaan Firman Allah). Semangat humanisme, Rasionalisme dan Pneumatis di bidang teologi dan homilitika bergabung dalam diri Melanchton.
Menurut Martin Luther $^{83}$

$(1483-1546)$ mengartikan bahwa:

Firman Tuhan adalah Kristus, Alkitab dab kotbah gereja.jika satu dari ketiga unsur ini tidak ada, maka bagi Luther bukan merupakan Firman Tuhan. Tuhan menyatakan diri-Nya dalam Yesus Kristus. Firman itu telah menjadi daging dan kenyataan itulah yang menjadi Suci (Alkitab). Dalam visi ini kotbah gereja menjadi Firman Tuhan. Karena firman yang telah menjadi daging itu menjadi nyata dalam Alkitab, maka kotbah gereja menjadi pemberitaan Firman Tuhan.

Selanjutanya ia juga menegaskan bahwa:

Dalam kotbah Roh Tuhan bekerja, dan tidak mungkin dipisahkan Kristus dengan Roh dan tidak mungkin pula dipisahkan Alkitab dengan Roh serta tak mungkin dipisahkan antara Roh dan Firman. Firman sanggup memimpin manusia menuju iman kepada Tuhan. Firman dan Roh dapat disamakan dengan nafas dan suara yang tidak dapat dipisahkan.Roh dapat diterima dan diakui kebenarannya hanya apabila Roh itu sunggung-sungguh masuk ke dalam sejarah. Nafas yang menyatakan diri dalam suara itulah nafas yang sebenarnya.Suara Roh Tuhan sudah menjadi nyata melalui Firman Tuhan, yakni Alkitab. Oleh sebab itu Firman Tuhan (Alkitab) perlu dikotbahkan. Tanpa kotbah tak mungkin Roh itu menyentuha seseorang. Roh membutuhkan Firman (Alkitab) dan Firman (Alkitab) membutuhkan Roh. Firman benar-benar menjadi Firman bila disampaikan dan diberitakan kepada kita demi Roh, tetapi secara material tidaklah mengandung Roh.

Bagi Martin Luther Firman Tuhan dengan Alkitab tidak identik. Alkitab tidaklah otomatis Firman Tuhan. Tetapi Alkitab menjadi Firman Tuhan bila yang tertulis dalam Alkitab, dengan perantaraan Roh menjadi injil kemenangan Kristus yang dikotbahkan oleh pengkotbah. Firman yang tertulis didalam Alkitab tetapi tidak diberitakan, sama sekali tidakmempunyai arti. Firman Tuhan yang tertulis mempunyai arti apabila telah diberitakan. Pemberitaan terjadi bila Firman itu dikotbahkan. Setiap penafsir dan pengkotbah sedapat mungkin harus melakukan tafsiran yang historis, kristologis, tipologis dan evangelis. Zwingly dalam kaitannya dengan homilitika, menyatakan bahwa: ${ }^{84}$

Kotbah itu adalah eksplicatio (menggali isi Firman Tuhan) dan aplicatio (menghubungkan dengan kehiduan yang konkret). Ciri khas dari kotbh Zwingly ialah Eksegetis, Humanis, Spiritualis dan Sosial Politis. Ciri Eksegetis adalah ciri yang dipelopori oleh Zwingly, yakni langsung menafsirkan isi Alkitab. Ciri Humanistis merupakan pengaruh dari humanismen pada zaman nya. Humanisme menekankan kemanusiaan manusia.Ciri Spiritualis, dalam usaha Zwingly didasarkan pada prinsip-prinsip gerakan pemikiran humanisme atas pengajaran Alkitab. Ciri Sosial politis ialah kensekuensi dari gerakan humanis keagamaan, sebab humanime itu menyangkut semua budang kemasyarakatan (kultural, ekonomi, sosial, politik).

${ }^{83} \mathrm{Ibid}, 13$.

${ }^{84}$ Killinger, Dasar-dasar Kotbah, 17. 
Zwingly juga menyatakan bahwa hubungan Alkitab dan kotbah tidak begitu mudah dicirikan dan ditentukan. Yang jelas kotbah itu harus didasarkan pada Alkitab. Lebih atau kurang dari itu tidak lagi merupakan Firman Allah. Dalam hal ini Roh Kudus sangat berperan. Adanya Firman Allah dalam Alkitab adalah karena kekuasaan Roh Kudus. Ini senada dengan pengertian Martin Luther tentang roh, Zwingly mengutamakan "sensus anagogicus" yaitu menggali pengertian yang tersirat (Alkitab) sebagai isi kotbah.

Sama halnya dengan Martin Luther, Johanes Calvin juga memberikan sumbangan yang penting di bidang homilitika. Bagi Calvin, Alkitab merupakan otoritas tunggal untuk kotbah, gereja dan umat Kristen secara perorangan. Tetapi Alkitab tidaklah secara otomatis identik dengan Firman Tuhan. Alkitab hanyalah alat atau instrumen yang digunakan Tuhan untuk menyatakan kehendak Nya dan memberitakan serta memasyurkan Perjanjian Tuhan bagi umat Nya. Dan dalam hal ini hanya berlaku bagi orang yang mempercayai Roh Kudus dan Firman Tuhan dalam Alkitab. Roh Kudus adalah benarbenar Roh Tuhan yang mempunyai otoritas untuk berfirman di dalam Alkitab. Bagi Calvin, Roh Kudus dan Alkitab mempunyai hubungan yang korelatif, saling mempengaruhi, saling menentukan satu sama lain.

Roh menyatakan diri dalam Alkitab dan Alkitab tidak mempunyai arti sama sekali tanpa "pemerintahan Roh" yaitu Roh yang memerintah, mengawasi, memberi ide, juga menghardik dan memperingati. Adanya hubungan korelatif antara Alkitab dan Roh memberikan kesaksian yang kuat bagi Calvin untuk menyatakan dan mengajarkan bahwa hanya Alkitab yang memiliki otoritas tunggal bagi gereja dan menjadi satu-satunya norma bagi iman Kristen. Hal ini sesuai dengan ajaran Luther "sola scriptura" (hanya Alkitab).

Menurut Calvin, hanya dengan pertemuan antara Firman Tuhan dalam Alkitab dengan manusia, maka timbul iman kepercayaan. Kemahakuasaan Roh membuat kata-kata dalam Alkitab menjadi Firman Tuhan. Kotbah menurut Calvin merupakan kelanjutan tugas kenabian . Kotbah adalah tanda anugreah Allah yang besar terhadap kita oleh karena Allah melalui kotbah berbicara dengan manusia. Demi anugerah Tuhan maka suara, perkataan dan bahasa yang terbatas di pakai menjadi alat Tuhan. Perkatan an bahasa manusia dimuliakan dan diberkati agar dalam perkataan dan melalui manusia, suara Tuhan menjadi nyata.

\section{Definisi Operasional Variabel Kotbah}

Berdasarkan uraian diatas maka dapat disusun definisi operasional dari variable kotbah adalah penyampaian firman Tuhan oleh seorang hamba Tuhan.

\section{Konstruk Variabel Kotbah}

\begin{tabular}{|c|c|c|}
\hline \multirow{12}{*}{ Khotbah } & \multirow{4}{*}{ Pengkhotbah } & Lahir baru \\
\hline & & Perilaku \\
\hline & & Karakter \\
\hline & & Moralitas \\
\hline & \multirow{4}{*}{ Isi Khotbah } & Alkitabiah \\
\hline & & Ekspositori \\
\hline & & $\begin{array}{c}\text { Relevansi ke masa } \\
\text { kini }\end{array}$ \\
\hline & & Mudah dipahami \\
\hline & \multirow{4}{*}{ Penyampaian } & Jelas \\
\hline & & Simpatik \\
\hline & & Menyakinkan \\
\hline & & Sederhana \\
\hline
\end{tabular}

\section{Perumusan Hipotesis}

Berdasarkan landasan teori yang telah di jabarkan diatas maka penulis merumuskan hipotesis keempat $(\mathrm{H} 4)$ sebagai berikut: H4: Ada pengaruh Kotbah terhadap Komitmen Organisasi Jemaat bergereja. Dengan mengacu pada pengertian diatas maka penelitian ini menggunakan cara untuk mengumpulkan data melalui penlitian lapangan (Field Research). Paradigma yang digunakan adalah paradigma kuantitatif, dimana penelitian ini menggunakan peralatan statistik guna melakukan analisa data yang ada yang berasal dari obeservasi literatur dan penelitian lapangan. Setelah mengadakan observasi awal dan studi literatur maka penulis kemudian menentukan Research Question. Dari sinilah kemudian timbul rumusan masalah. Dari rumusan masalah kemudian penulis melakukan telaah teoritis dan kemudian merumuskan hipotesis.

Selanjutnya penulis melakukan pemilihan data dengan menentukan populasinya dan menentukan sampel dan kriteria responden yang diinginkan. Selanjutnya adalah membuat kuisioner yang dirancang berdasarkan rumusan masalah yang telah ditentukan semula.

Hasil yang didapat kemudian diuji terlebih dahulu validitasnya dan reliabilitasnya. Kedua uji ini adalah persyaratan yang diperlukan sebelum kita mengadakan analisis data. Uji validitas didefinisikan sebagai ukuran seberapa kuat atau akurat suatu alat ukur melakukan 
fungsi ukurnya. Semakin tinggi validitas suatu variabel maka alat ukur tersebut semakin mengenai sasarannya dan semakin menunjukkan apa yang seharusnya ditunjukkannya Uji selanjutnya adalah Uji reliabilitas. Uji reliabilitas menunjukkan sejauh mana alat pengukur dapat dipercaya atau diandalkan. Keandalan disini dapat berarti berapa kalipun variabel-variabel tersebut ditanyakan pada responden yang berlainan maka hasilnya tidak akan menyimpang terlalu jauh dari rata-rata jawaban responden untuk variabel tesebut atau dengan kata lain reliabilitas dapat menunjukkan konsistensi suatu alat ukur didalam mengukur gejala yang sama.

Setelah uji validitas dan reliabilitas telah dilakukan dengan hasil yang memenuhi persyaratan maka langkah selanjutnya adalah analisa regresi. Parameter regresi diuji secara serentak menggunakan Analysis of Variance (Anova). Anova digunakan untuk menguji ketepatan garis regresi yang ditaksir.

\section{POPULASI DAN SAMPEL}

Tahap pertama yang dilakukan peneliti dalam pemilihan sampel adalah mengidentifikasi populasi target (Target Population). Penelitan yang menggunakan sampel yang memenuhi syarat akan memberikan hasil yang mempunyai kemampuan untuk digeneralisir. Kriteria sampel yang representatif tergantung pada dua aspek yang saling berkaitan yaitu: akurasi sampel dan ketelitian sampel. Populasi target dalam penelitian ini adalah jemaat gereja GKI Dasa Surabaya.

Sampel diambil dengan metode stratified random sampling yaitu jemaat yang telah menjadi anggota lebih dari 5 th. Sementara Sample framenya adalah jemaat yang terdaftar sebagai anggota gereja GKI Dasa Surabaya. Sementara jemaat yang sifatnya partisipan pada gereja tertentu atau tidak terdaftar dalam jemaat gereja tertentu tidak termasuk didalamnya. Kemudian diadakan seleksi terhadap kuisioner yang kembali tersebut sesuai dengan criteria yang ditetapkan.

\section{KRITERIA RESPONDEN}

Dalam penelitian ini yang ditetapkan menjadi responden adalah terdaftar sebagai anggota jemaat GKI Dasa minilmal selama 5 tahun. Responden adalah jemaat yang dewasa secara umur minimal 20 tahun.

\section{KESIMPULAN}

Kesimpulan yang dilakukan pada penelitian ini terdiri dari dua kategori, yaitu kesimpulan berdasarkan kategori individu (responden) dan kesimpulan berdasarkan hipotesis.Kesimpulan Berdasarkan Katagori Individu /RespondenPada kesimpulan ini dijelaskan katagori individu/ responden berdasarkan katagori responden, usia, jenis kelamin, kepengurusan (pernah/tidak atau sedang menjabat sebagai pengurus), dan pendidikan terakhir, antara lain:

Pertama, Responden berdasarkan kategori usia terhadap komitmen organisasi maka responden muda cenderung berkomitmen tinggi atau tingkat komitmen organisasi responden tinggi diikuti dengan responden dewasa dan responden tua.

Kedua, Responden berdasarkan jenis kelamin wanita cenderung lebih tinggi dibandingkan dengan responden laki-laki terhadap komitmen organisasi.

Ketiga, Responden berdasarkan tingkat pendidikan terhadap komitmen organisasi, menunjukkan tingkat pendidikan golongan pasca sarjana menampati peringkat tertinggi, diikuti dengan golongan sarjana dan golongan SMA. Keempat, Responden berdasarkan kepengurusan terhadap komitmen organisasi memiliki kecenderungan penilaian tinggi pada responden yang tidak pernah menjabat sebagai pengurus dari pada yang pernah menjabat atau sedang menjabat sebagai pengurus.

\section{Kesimpulan Berdasarkan Hipotesis}

Hipotesis yang diajukan dalam penelitian ini sebanyak empat hipotesis. Kesimpulan dari empat hipotesis tersebut adalah sebagai berikut:

Pertama, Kesimpulan mengenai H1. H1: Dari Hasil ANOVA Gaya kepemimpinan, ketrampilan komunikasi dan kotbah secara bersama-sama berpengaruh terhadap komitmen organisasi secara signifikan sebesar 75,578. Sedangkan dari nilai koefisien determinasi adalah sebesar $71.1 \%$, sisanya yaitu $28,3 \%$ dipengaruhi oleh variabel yang lain. (terima $\mathrm{H} 1$ ).

Kedua, Kesimpulan mengenai H2. H2 : Gaya kepemimpinan berpengaruh signifikan terhadap komitmen organisasi sebesar 9,001 dengan signifikan pada 0,05 , sehingga dapat disimpulkan ada hubungan kuat atau konstruk / variabel gaya kepemimpinan berpengaruh signifikan terhadap komitmen organisasi (terima $\mathrm{H} 2$ ).

Ketiga, Kesimpulan mengenai H3. H3 : Ketrampilan komunikasi berpengaruh signifikan terhadap komitmen organisasi .Hubungan antara ketrampilan komunikasi terhadap komitmen organisasi memberikan nilai parameter sebesar 7,899 dengann signifikan pada 0,05 , sehingga dapat disimpulkan terdapat hubungan atau konstruk/ variabel ketrampilan komunikasi berpengaruh signifikan terhadap komitmen organisasi (terima $\mathrm{H} 3$ ).

Keempat, Kesimpulan mengenai H4. H4 : Kotbah berpengaruh signifikan terhadap komitmen organisasi. Hubungan antara kotbah terhadap komitmen organisasi memberikan nilai parameter 7,899 dan signifikan pada 0,05 , sehingga dapat disimpulkan terdapat hubungan atau konstruk/ variabel kotbah berpengaruh signifikan terhadap komitmen organisasi (terima $\mathrm{H} 4$ ).

\section{SARAN}

Pertama, dengan melihat bahwa variabel Gaya Kepemimpinan adalah variabel yang paling dominan yang mempengaruhi komitmen organisasi jemaat bergereja maka disarankan kepada para gembala dan pengkotbah untuk lebih meningkatkan baik kualitas kepemimpinan mereka dengan menambah pengetahuan 
tentang kepemimpinan dan khususnya gaya kepemimpinan. Karena secara teoritis hal tersebut dapat dikembangkan dan setiap pemimpin punya kesempatan untuk mengembangkan gaya kepemimpinannya untuk lebih kondusif terhadap proses penggembalaan yang sedang berlangsung di gereja lokal.

Gembala sebagai pemimpin juga perlu melibatkan diri dengan interaksi yang bersahabat dalam kegiatankegiatan di dalam jemaat sambil memastikan semua bawahan atau pekerja dan pihak-pihak yang terkait bekerja sesuai tanggung jawab dan perannya masingmasing.

Yesus Kristus merupakan pemimpin sejati sepanjang masa. Pemimpin gereja lokal dapat belajar dan menimbah inspirasi dari-Nya, untuk menjadi pelayan, gembala dan pengurus dengan kemampuan memaknai, memampukan, memberdayakan dan mendorong. Kiranya dengan spiritualitas yang mendalam dan keterampilanketerampilan yang memadai dalam kepemimpinan, pemimpin jemaat dapat mendorong terjadi proses penggembalaan yang benar guna mencapai perubahanperubahan yang bernilai dalam komunitas dan Gereja.

Kedua, ketrampilan berkomunikasi sangat dibutuhan bagi seorang publik figur seperti seorang gembala. Selalu mengembangkan dan mempersiapkan diri untuk menjadi publik figur yang memiliki ketrampilan komunikasi adalah hal yang perlu bagi seorang gembala. Selain pengetahuan teologia ilmu komunikasi juga menjadi pengetahuan yang harus dimiliki oleh setiap pemimpin gereja lokal atau pemimpin jemaat. Secara fakta dibuktikan bahwa jemaat membutuhkan seorang gembala yang tahu bagaimana berkomunikasi yang optimal. Komunikasi tidak hanya yang bersift verbal namun juga komunikasi yang bersifat non verbal. Ketidak tahuan tentang ketrampilan komunikasi yang baik akan menjadi hambatan tersendiri bagi proses penggembalaan di gereja lokal.

Ketiga, kotbah adalah tugas yang sangat penting bagi gembala. Gembala yang baik adalah gembala yang mengenal kebutuhan makanan domba-dombanya. Ia akan memberikan makanan kepada domba-dombanya seturut dengan kebutuhan masing-masing. Kotbah yang baik akan membuat jemaat mersa gembala benar-benar tahu apa yang menjadi pergumulan pribadi mereka. Kotbah yang baik juga tidak bertele-tele dan membingungkan jemaat. Domba yang menerima makanan yang sesuai dan mengena kepada kebutuhannya akan merasa bahwa gembalanya mengenal dia dengan baik, tetapi domba yang tidak diberi makan sesuai dengan kebutuhannya akan merasa bahwa gembalanya tidak mengenalnya dengan baik dan ia bukan bagian dari persekutuan yang ada. Tema kotbah yang berseri tentang topik-topik tertentu juga menanamkan secara kuat kepada jemaat tentang apa yang sebenarnya maksud firman Tuhan.

\section{KEPUSTAKAAN}

[1] AloLiliweri, Dasar-dasar Komunikasi Antar Budaya (Yogyakarta:Pustaka Pelajar. 2004).

[2] Anthony D'Souza, Proactive Visionary Leadership (Jakarta: Trisewu, 2007).

[3] Brian H. Spitzberg, dan William R. Cupach, "Interpersonal Communication Competence" (t.k.: SAGE Publications, 1984).

[4] Cut Zurnali, "Learning Organization, Competency, Organizational Commitment, dan Customer Orientation: Knowledge Worker Kerangka Riset Manajemen Sumber Daya Manusia di Masa Depan,"(Bandung: Unpad Press, 2010).

[5] Djuwita, Forum Manajemen Strategis dan Pengembangan SDM (t.k.: t.p., 2008).

[6] Edah Jubaedah, Analisis Hubungan Gaya Kepemimpinan dan Kompetensi Komunikasi dalam Organisasi. Jurnal Ilmu Administrasi, Volume VI No. 4 Desember 2009. (t.k.: t.p., 2009).

[7] F. Jablin, dan Linda L.Putnam, Communication competence. InThe new handbook of organizational communication: Advances in theory, research, and methods, eds. Thousand Oaks, (CA: Sage,2001).

[8] FandyTjiptono, "StrategiPemasaran.”EdisiKedua. CetakanKelima. (Yogyakarta: Andi Offset, 2001).

[9] FredLuthan, Organizational Behavior(New York: Mc Graw-Hill Comp., 2002).

[10] G. R. Ferris, Witt, L. A., dan Hochwarter, W. A., The Interaction Of Social Skill And General Mental Ability On Work Outcomes. Journal of Applied Psychology, 2001.

[11] Ginting, Kotbah dan Pengkotbah (t.k.:t.p., t.t.)

[12] Hanny Layantara, "IlmuKomunikasi". Diktat STTII Surabaya, 2006.

[13] Hasan Sutanto, "Homiletik Prinsip dan Metode Berkotbah” (Malang: Literatur SAAT, 2007).

[14] Heidjrachman dan Suad Husnan,"Manajemen Personalia.” Cetakan kedua. (Yogyakarta: BPFE, 2002).

[15] Hersey, "Kunci Sukses Pemimpin Situasional"(Jakarta: Delaprasata,2004).

[16] Holly J. Payne, Western Kentucky University, "Reconceptualizing Social Skills in Organizations: Exploring the Relationship between Communication Competence, Job Performance, and Supervisory Roles," Journal of Leadership and Organizational Studies, SAGE Journals, Winter 2005, Vol. 11 no. 2.

[17] Igantius Suharyo, Yang Terpilih untuk Dipecah dan Dibagi (Yogyakarta: Kanisius, 2009).

[18] Kamus Besar Bahasa Indonesia, Pusat Bahasa, Dep.Dik. Nas. 2008.

[19] Kartono Kartini, Pemimpin dan Kepemimpinan (Jakarta : PT. Raja Grafindo Persada, 2005). 
[20] Keith Davis \& John W. Newstrom, Perilaku Dalam Organisasi. Edisi Ketujuh.Terjemahan. (Jakarta: Erlangga, 1995).

[21] Killinger, Dasar-dasar Kotbah. L.O. Cooper, Listening Competency in the Workplace: A Model for Training (t.k.: Business Communication Quarterly, 1997).

[22] M. Amstrong, A Handbook of Human Resource Management, Terjemahan (Jakarta: Elex Media Komputindo, 1994), t.h.

[23] M. Asrori, Pengembangan Peserta Didik (Malang: Wineka Media, t.t.).

[24] Manthis, dan Jackson, ManajemenSumberDayaManusia.EdisiPertama. CetakanPertama (Yogyakarta: SalembaEmpat, 2002).

[25] Meyer, dan Allen, Ommitment in Work Place: Theory, Research, and Application" (t.k.:SagePublications, 1997).

[26] MiftahThoha, KepemimpinandalamManajemen (Jakarta: RajawaliPers, 1983).

[27] Mimery, Rahasia tentang Penggembalaan (t.k.: Mimery Pressindo Multimedia, t.t.).

[28] Noor Anggarito, MenyiapkanKotbahEkspositoriSecaraPraktis (Yogyakarta: Andi, 2008).

[29] Northouse, "Leadership: Theory and Practice," Paul Hersey dan Ken Blanchard, "Leader Effectiveness dan Adaptability Description" (t.k.: t.p., 1988).

[30] Peter C. Wagner, Gereja Saudara dapat Bertumbuh (Malang: Gandum Mas, 2003).

[31] R.A. Baron, dan J.Greenberg,Behavioral in Organization. Edisi ketiga.Understanding and Managing the Human Side Work(t.k.: t.p., 1990).

[32] R. L. Duran, dan Spitzberg, B. H., Toward The Development And Validation Of A Measure Of Cognitive Communication Competence (t.k.: Communication Quarterly, 1995).

[33] R. M. Steers, Motivation and Work Behavior Edisi ke 3 (USA: McGraw Hill Book Company, 1988).

[34] Rick Warren, ThePurpose Driven Church. Cetakan ke-1 (t.k.: Yayasan Gandum Mas, 1999).

[35] Ricky W.Griffin, Manajemen. Edisi ke 7. Jilid 2. Penerjemah: Gina Gania (Jakarta: Penerbit Erlangga, 2004).

[36] Robert J. Stevens, Management Versus Leadership. 28 Februari 2006.

[37] Robert R. Siahaan, Umat Kristen Tanpa Komitmen, Tabloid Reformata Edisi 153 Juli 2012, Yayasan Pelayanan Media Antiokhia.

[38] Sonny Eli Zaluchu, Intrik dalam Gereja.

[39] StephenRobbin, danAnthony A Judge,Perilaku Organisasi. Edisi 12. Buku 1. (Jakarta: Salemba Empat, 2008).

[40] Sugianto, Membangun Komitmen Hidup Jemaat Dalam Gereja(Lawang: STTIA, 2011), t.h.

[41] Yakob Tomatala, Kepemimpinan Kristen (t.k.: t.p., 2002).
[42] Zurnali, Learning Organization.

[43] www.aligningaction.com/comcomp.html. Rowley, Richard D. 2002. Communicatio Competence: The Essence of Aligning Action.

[44] www.danielronda.com/index.php/kepemimpinan 155-kajian-atas-kepemimpinan-model-gembala.html

[45] www.glorianet.org/kolom/kolointr.html; Gloria Cyber Ministries.

[46] www.hikmatpembaharuan.wordpress.com/2012/ 06/26/pemikiran-tentang-pemuridan-beberapaprinsip-penting/

[47] www.infodokterku.com/component/content/artic le/28-info-khusus/info-kristiani-sebelumnya/191inilah-penyebab-jemaat-pindah-gereja.

[48] www.rajaprestasi.com/2009/05/menumbuhjankomitmen-dan-motivasi-pada-karyawan/

[49] www.reformata.com/new/view/6651/umatkristen-tanpa-komitmen.

[50] www.wikipedia.org. 